\title{
These Are the Good Old Days: Foreign Entry and the Mexican Banking System
}

\section{Citation}

Haber, Stephen, and Aldo Musacchio. "These Are the Good Old Days: Foreign Entry and the Mexican Banking System." Harvard Business School Working Paper, No. 13-062, January 2013.

\section{Permanent link}

http://nrs.harvard.edu/urn-3:HUL.InstRepos:10208236

\section{Terms of Use}

This article was downloaded from Harvard University's DASH repository, and is made available under the terms and conditions applicable to Open Access Policy Articles, as set forth at http:// nrs.harvard.edu/urn-3:HUL.InstRepos:dash.current.terms-of-use\#OAP

\section{Share Your Story}

The Harvard community has made this article openly available.

Please share how this access benefits you. Submit a story.

\section{Accessibility}


H A R VAR D

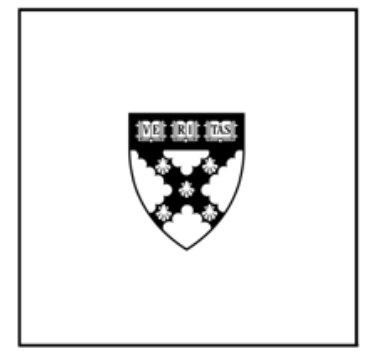

\section{These Are the Good Old Days: Foreign Entry and the Mexican Banking System}

Stephen Haber

Aldo Musacchio

\section{Working Paper}

13-062

January 10, 2013 


\title{
These Are the Good Old Days:
}

\section{Foreign Entry and the Mexican Banking System}

\author{
Stephen Haber
}

And

Aldo Musacchio**

** Haber is Peter and Helen Bing Senior Fellow of the Hoover Institution and A.A. and Jeanne Welch Milligan Professor, Department of Political Science, Stanford University. He is also a Research Economist at the National Bureau of Economic Research. Musacchio is an Associate Professor of Business, Government, and the International Economy at the Harvard Business School, and a Research Fellow at the National Bureau of Economic Research. 


\section{SUMMARY \\ THESE ARE THE GOOD OLD DAYS: \\ FOREIGN ENTRY AND THE MEXICAN BANKING SySTEM}

In 1997, the Mexican government reversed long-standing policies and allowed foreign banks to purchase Mexico's largest commercial banks and relaxed restrictions on the founding of new, foreign-owned banks. The result has been a dramatic shift in the ownership structure of Mexico's banks. For instance, while in 1991 only one percent of bank assets in Mexico were foreign owned, today they control 74 percent of assets. In no other country in the world has the penetration of foreign banks been as rapid or as far-reaching as in Mexico. In this work we examine some of the important implications of foreign bank entry for social welfare in Mexico. Did liberalization lead to an increase (or decrease) in the supply of credit? Did liberalization lead to an increase (or decrease) in the cost of credit? Did liberalization lead to an increase (or decrease) in the stability of the banking system?

In order to answer these questions, we must first ask, "increase (or decrease), measured on what basis?" There are, in fact, two distinct conceptual frameworks through which one can assess the impact of foreign bank entry. One is concerned with measuring the short-run impacts of foreign entry on credit abundance, pricing, and observable stability using reduced form regressions. The other is an institutional economics conception of how to measure performance. It is focused on understanding whether foreign entry gave rise to difficult-to-reverse changes in the political economy of bank regulation, which will affect competition and stability in the long term, outside the period that may be observed empirically. We employ both conceptions in this paper. 
When we look at the impact of foreign entry using econometrics, the evidence strongly indicates that Mexico's banking system is now much more stable. The ratio of nonperforming loans has declined dramatically, while equity ratios have increased. System stability does not appear to have come at the cost of a decrease in the availability of credit. In fact, credit to firms and households has increased in real terms. System stability also does not appear to have come at the cost of higher priced credit. In fact, the evidence suggests that foreign banks charge lower interest spreads than domestically-owned banks.

When we take a broader, political economy view of the impact of foreign bank entry in Mexico, the evidence indicates that there if there ever was a "good old days" of Mexican banking, in which credit was abundant and the system was stable, we are in it. From the 1920s through the 1960s the Mexican banking system was stable, but it provided very modest amounts of credit to firms and households. Moreover, the stability of the system may have been an artifact of the ability of commercial banks to shift risk to government-owned development banks, which is to say that risk was quietly shifted to taxpayers. The banking system that existed in Mexico from the 1970s until 1997 was characterized by periods of rapid credit growth, followed by devastating busts, the aftermaths of which were characterized by very low levels of credit provision. Indeed, the Mexican banking system during this period was, by the standards of the rest of the world, extraordinarily unstable.

In order to understand the reasons why the Mexican government changed its longstanding policies against foreign ownership in the late 1990s, we examine the terms of play between banks and the state in Mexico using the so-called "game of bank bargains" of Calomiris and Haber (forthcoming), which sees the banking system as a partnership between 
financiers, the parties in control of the government, and the groups that the government views as essential to maintaining its hold on power.

We use this framework to explain why and how the bank privatization of 1991-92 had built-in incentives for moral hazard. That is, the government was able to craft a partnership, but the terms of that partnership meant that the bankers had very little to lose if something went wrong. This perverse alignment of incentives produced reckless lending from 1992 to 1995, which resulted in a banking crisis (1995-96), an expensive bailout, and the rejection of the PRI by voters in 1997 and 2000.

When the government of Ernesto Zedillo thought about how to craft a stable partnership after rescuing the banks in 1995-96, it was therefore very cautious when it came to choosing its partners, lest it be politically exposed again. Rather than choosing to partner with domestic financiers, the Zedillo government chose a set of large, foreign-owned banks. From the point of view of the Zedillo government, foreign partners had four advantages: 1) they could be counted on recapitalize the banks with real (not fictitious) capital; 2) they did not own downstream non-financial enterprises that they be induced to save during a crisis by tunneling into their own banks; 3) they could not reasonably expect to be bailed out by the government in the event of a crisis; and 4) their managements might be concerned about not running afoul of regulators and stockholders in their home countries. In short, foreign bankers had a lot to lose if they mismanaged their end of the partnership. In our econometric results we show that the behavior of foreign banks, both those that acquired Mexican banks and the de novo operations, is consistent with our political economy analysis that the bank partnership is today more stable as a consequence of foreign bank entry. 


\section{Introduction}

For the past 15 years Mexico has been engaged in an ambitious experiment. Mexico's banking system had been closed to foreign competition throughout most of the $20^{\text {th }}$ century. ${ }^{1}$ In 1997, however, the Mexican government reversed long-standing policies and allowed foreign banks to purchase Mexico's largest commercial banks. It also relaxed restrictions on the founding of new, foreign-owned banks in Mexico. The result has been a dramatic shift in the ownership structure of Mexico's banking industry. In 1991, only one percent of bank assets in Mexico were foreign owned. By 1996, on the eve of the reforms, the proportion was still only 7 percent. After the bank ownership rules were changed, the proportion of bank assets under foreign ownership jumped to 20 percent in 1998 , to 57 percent by 2000 , and to 82 percent by 2002. As of the end of 2011, it was 74 percent. (See Table 1 and Figure 1). Other countries, including the United States, Canada, Chile, Colombia, Brazil, Turkey, the Philippines, and much of Western Europe, also opened up their banking sectors to foreign competition at roughly the same time. In no other case, however, has the penetration of foreign banks been as rapid or as far reaching as in Mexico.

The decision to allow foreign banks to enter the Mexican market has important implications for social welfare. Did liberalization lead to an increase (or decrease) in the supply of credit? Did liberalization lead to an increase (or decrease) in the cost of credit? Did liberalization lead to an increase (or decrease) in the stability of the banking system?

${ }^{1}$ As a practical matter, Mexico's banks had been majority owned by domestic interests since the 1930s. This situation was codified in 1966 by President Gustavo Díaz Ordaz, who ordered that the banking industry had to be domestically owned. This was part of a more general initiative under Díaz Ordaz to force foreign investors across a broad range of enterprises to sell majority stakes to Mexican owners. (Izquierdo 1995: 112, 119). 
In order to answer these questions, we must first ask, "increase (or decrease), measured on what basis?" There are, in fact, two distinct conceptual frameworks through which one can assess the impact of foreign bank entry. One of these is based on the financial economics conception of banking system performance. It is concerned with measuring the short-run impacts of foreign entry on credit abundance, pricing, and observable stability using reduced form regressions. The other is an institutional economics conception of how to measure performance. It is focused on understanding whether foreign entry gave rise to difficult-to-reverse changes in the political economy of bank regulation, which will affect competition and stability in the long term, outside the period that may be observed empirically. We employ both conceptions in this paper. We employ reduced form regressions in order to estimate the effects of foreign entry on the pricing and availability of credit, as well as the effects of foreign entry on the stability of the banking system. We also, however, assess changes in the institutions that underlie the Mexican banking system, comparing the incentives generated under a system of foreign owned banks against those that existed in Mexico since the 1920s. In short, in order to answer the question "did the liberalization of foreign entry enhance welfare," we draw on analytic tools from financial economics, economic history, and political science.

When we look at the impact of foreign entry using the tools financial economics, the evidence strongly indicates that Mexico's banking system is now much more stable. The ratio of non-performing loans has declined dramatically, while equity ratios have increased. System stability does not appear to have come at the cost of a decrease in the availability of credit. In fact, credit to firms and households has increased in real terms. System stability 
also does not appear to have come at the cost of higher priced credit. In fact, the evidence suggests that foreign banks charge lower interest spreads than domestically-owned banks.

When we take a broader, political economy view of the impact of foreign bank entry in Mexico, the evidence indicates that there if there ever was a "good old days" of Mexican banking, in which credit was abundant and the system was stable, we are in it. From the 1920s through the 1960s the Mexican banking system was stable, but it provided very modest amounts of credit to firms and households. Moreover, the stability of the system may have been an artifact of the ability of commercial banks to shift risk to government-owned development banks, which is to say that risk was quietly shifted to taxpayers. The banking system that existed in Mexico from the 1970s until 1997 was characterized by periods of rapid credit growth, followed by devastating busts, the aftermaths of which were characterized by very low levels of credit provision. Indeed, the Mexican banking system during this period was, by the standards of the rest of the world, extraordinarily unstable.

Thinking about the consequences of foreign bank entry in Mexico in a long-term context is not just about specifying the right comparison; it is about understanding the reasons why the Mexican government changed its long-standing policies against foreign ownership in the late 1990s, and is about understanding why that change in policy has fundamentally altered the terms of play between banks and the state in Mexico. As we shall show in the pages that follow, the events leading up to the liberalization of the banking laws in 1997, including the bank expropriation of 1982, the privatization of 1991-92, and the rescue of the banking system in 1995-96, were all part of a much larger game that was being played between a government with few limits on its authority and discretion and a group of bankers, who could only operate within the confines of a legal and regulatory environment that was 
under the control of the government. The liberalization of foreign entry changed that game: it is much harder for the government to behave opportunistically toward the banks, but it is also much harder for the banks to pass along losses to taxpayers.

We proceed as follows. In Section Two we discuss the relevant academic literatures. In Section Three we draw on the extant literature to provide a logical framework that can order the facts related to the events that led up to the decision to liberalize Mexico's banking system in 1997, as well as to order the facts related to the behavior of Mexico's banks after liberalization in 1997. In Section Four we examine the economic and political history of Mexico's banking system in the $20^{\text {th }}$ century, focusing in particular on the impact of the expropriation of the banks in 1982, the privatization of those expropriated banks in 1991-92, and the government's need to bail out (and in some cases re-nationalize) those same banks in 1995-96 because of flaws that were built into the design of the privatization program. In Section Five we employ the facts from Section Four to develop an econometric strategy with which to measure the welfare effects of foreign entry. We also introduce the unique dataset we have constructed. Section Six leads the reader through the analysis of the data. Section Seven then embeds the econometric results into the logical framework we introduce in Section Three. It also presents our conclusions. 


\section{Section Two}

\section{Literature Review}

There are three bodies of scholarship that are relevant to our study of the effects of foreign bank entry in Mexico. The first of these is the financial economics literature on foreign entry in middle income countries. The second of these is the political economy literature on banking systems as an implicit partnership between governments and financiers. The third is the literature on the economic and political history of banking in Mexico.

\section{The Financial Economics Literature on Foreign Entry}

Mexico is not the only country that has opened its banking system to foreign entry. As a result, there is a sizable financial economics literature that attempts to estimate the short-run impact of foreign entry. This literature employs reduced form regressions designed to detect robust associations between foreign market shares or foreign ownership with administrative costs or net interest margins. The nature of the enterprise is necessarily short-run in nature: over the long-run, the equilibrium outcome will be that inefficient banks will disappear from the system, so that all banks, regardless of ownership will price credit identically.

Most of the studies that have emerged from this research conclude that foreign entry increases the contestability of markets, thereby reducing administrative costs, lowering net interest margins (NIMs), and driving down bank rates of return. Nevertheless, as Clarke, Cull, Martínez Peria, and Sánchez (2004) note, much of what we know comes from cross-country studies that are heavily weighted toward developed economies. This is particularly crucial because the impact of foreign entry may vary with the level of economic development (Lensink and Hermes 2004; Claessens, Demirguç-Kunt, and Huizinga, 2001). 
As a consequence, scholars have recently turned their attention to the impact of foreign entry in middle-income countries. As of yet, however, this literature does not provide a consensus set of results as to the likely direction or magnitude of the effects of foreign entry. There is evidence from some studies that foreign entry can negatively affect the pricing, level, and volatility of credit. Claessens, Demirguç-Kunt and Huizinga (2001) find that foreign banks operating in developing economies have higher overhead expenses, charge higher interest margins, and earn higher rates of return than domestic banks. Studies of Argentina and Pakistan suggest that foreign banks may also be less willing to extend credit on the basis of "soft knowledge" about firms than domestically-owned banks. Foreign entry may therefore give larger firms even greater advantages by exacerbating problems of differential access to capital (Clarke, Cull, D’Amato, and Molinari, 2000; Berger, Klapper, and Udell 2001; Mian 2006). Detragiache, Tressel, and Gupta (2006) find that foreign entry in developing economies is associated with a net reduction in total lending to the private sector: foreign banks appear to skim off the best credit risks, leaving domestic banks with a pool of weaker borrowers from which to select. A related body of research suggests that foreign banks represent a trade-off for a developing country. Galindo, Micco, and Powell (2004) develop a model and present evidence indicating that foreign banks may be less susceptible to funding shocks than domestic banks because they can tap capital from their home institutions, but at the same time foreign banks are more reactive to shocks that affect expected returns. That is, they may be more fickle than domestic lenders, leading to greater banking system instability.

There are also, however, studies that point to the opposite conclusion. Clarke, Cull, and Martínez Peria (2006) find that enterprises in countries with high levels of foreign bank 
participation tend to rank interest rates and access to long term loans as lesser constraints on their operations and growth than do enterprises in countries with low levels of foreign bank participation. Martínez Peria and Mody (2004), analyzing a group of Latin American cases, find that foreign banks charge lower interest rate spreads than domestically-owned banks. They also find that foreign bank entry is associated with an overall increase in administrative efficiency and a decrease in interest spreads, suggesting that foreign entry spurs competition. Denizer (1999), in a study of Turkey, obtains similar results: foreign entry reduced domestic bank overhead expenses as well as bank profitability. Unite and Sullivan (2003) find that foreign entry was associated with declines in interest rate spreads, overhead expenses, and profits in the Philippines. Havrylchyk (2006) finds that foreign banks in Poland are more efficient than domestic banks. Haber and Musacchio (forthcoming) find that there is little difference between foreign and domestic banks in Mexico in cross-section, but that foreign banks appear to have purchased under-performing Mexican banks.

The Fifth and Sixth sections of this paper draw heavily on the econometric techniques that have been developed in and refined in this body of literature.

\section{The Literature on the Political Economy of Bank Regulation}

A quite different literature, much of it written by economic historians or political scientists, takes a much broader approach. In this literature, banking regulation - and hence banking systems - is understood as equilibrium outcomes of a society's political institutions. Thus, the way to think about the impact of any particular change in the organization of a banking system, such as the decision to allow foreign entry, is to focus on the ways that change affects the incentives of the political and economic agents who operate within that system. 
This literature takes as its points of departure two core ideas. First, any government that is strong enough to arbitrate property rights is also strong enough to seize them for its own benefit. Second, the goal of government regulation is not to maximize social welfare; it is to sustain the existing political order, and permit the extant ruling groups to continue to rule. In order to understand the structure of regulation in any industry, therefore, one must understand the institutions that either constrain the government from behaving arbitrarily toward property owners or that compensate those property owners for the risk that the government will behave arbitrarily.

The origins of this literature go back at least as far as North and Weingast's (1989) study of the Glorious Revolution in England. Some of the subsequent literature in this tradition focused on Porfirian Mexico, most particularly (Maurer 2002), Haber, Razo, and Maurer (2003); Maurer and Gomberg (2004), and Maurer and Haber (2007). It has also spawned studies of other countries, such as Summerhill (forthcoming), as well as multicountry studies, or cross-country approaches, such as Barth, Caprio, and Levine (2006) and Haber, North, and Weingast (2007), Quintyn and Verdier (2010), and Calomiris and Haber (forthcoming). ${ }^{2}$ We draw on this literature, most particularly the theoretical framework developed in Calomiris and Haber (forthcoming), in Sections Three and Four of this paper.

\section{The Literature on the Economic and Political History of Banking in Mexico}

Theoretical frameworks must be married to facts in order to provide an interpretation. Fortunately, the past decade has given rise to an increasingly well-developed literature on the

${ }^{2}$ This literature developed in parallel with a more general literature about the role of institutions and economic growth. Notable examples include: Knack and Keefer (1995); Acemoglu, Johnson, and Robinson (2001, 2005); Engerman et. al., (2012). 
politics, economics, and history of banking in Mexico. Much of this literature is focuses on the Porfiriato and the Revolution. Salient works include Ludlow and Marichal (1985), Maurer (2002), Cerutti and Marichal (2003), Haber, Razo, and Maurer (2003), Maurer and Gomberg (2004), and Maurer and Haber (2007). There is also a increasingly rich literature on the economic history of Mexico during the $20^{\text {th }}$ century, much of it addressing issue related to banking and finance, such as Bazdresch and Levy (1991), Izquierdo (1995), Cárdenas (1996, 2000), Del Ángel-Mobarak (2002), and Moreno-Brid and Ros (2009). Finally, there is a growing and diverse literature, written from a variety of disciplinary perspectives, on the bank nationalization of 1982, the privatization of 1991-92, and the subsequent rescue and restructuring of the banking system. Salient works include Gruben and McComb (2003), Del Ángel-Mobarak, Bazdresch, and Suárez Dávila (2005), Murillo (2005), Haber (2005), Loaeza (2008), Del Ángel-Mobarak and Martinelli Montoya (2009), Suárez Dávila (2010), Espinosa Rugarcía and Cárdenas Sánchez (2011), and Haber and Musacchio (forthcoming). We draw on this literature in Section Four of this paper. 


\section{Section Three}

\section{Logical Framework}

Facts and data do not speak for themselves. Decisions about the ordering of facts, or the specification of statistical tests of data, require an organizing framework. We therefore build upon the framework in Calomiris and Haber (forthcoming) who construct a theory about banking systems and political institutions from first principles. They consider the incentives of all of the parties with a direct interest in the banking system - the majority shareholders, minority shareholders, depositors, debtors, and government actors — and then consider the ways that those parties can negotiate with one another under both autocratic and democratic forms of government. They then use this logical framework in order to understand variance in the stability and level of credit across societies.

Rather than recapitulating the (necessarily lengthy) Calomiris and Haber framework in its entirety, let us simply present some of its core insights. Their framework starts with the observation that underneath the seemingly simple set of transactions that are at the core of the business of banking — the pooling of equity and deposits, which are then lent to borrowers - is a rather thorny set of property rights problems. First, bankers (officers, directors, and majority shareholders) and the parties who control the government have to create mechanisms that either prevent the government from expropriating the banks once they are created, or that compensate the bankers for accepting the risk that they may be expropriated. Second, minority shareholders and depositors have to create mechanisms that either prevent the bankers from expropriating their capital through fraud or tunneling, or that that compensate them for accepting the risk that they may be expropriated. Third, banks have to create mechanisms that prevent borrowers from expropriating bankers, minority shareholders, and 
depositors by reneging on loan contracts, or they have to create mechanisms that compensate those groups for accepting the risk that they may be expropriated by borrowers.

These three commitment problems are not independent of each other: solving the problem of fraud or tunneling by bankers, and solving the problem of contract enforcement with debtors, necessarily involves the regulatory and police powers of the government — but any government with police powers strong enough to solve these problems is also strong enough to expropriate the banks! Consider the problem of fraud or tunneling by bank insiders: In the final instance, minority shareholders and depositors need the government to enforce contracting laws that make banks fulfill their obligations to them, pass and enforce laws against tunneling, and improve the chances that banks can be evaluated accurately by outsiders through the creation of accounting standards and regulatory and supervisory agencies. Depositors and shareholders also may look to the government to reduce their risks by creating de facto or de jure protections against loss (deposit insurance or bailouts).

Similarly consider the problem of contract enforcement by banks against borrowers: banks need the courts and police to enforce loan and other counterparty contracts; without them, collateral cannot be repossessed.

The problem is that the government is not a disinterested, independent party. This is true in three important senses. First, the coalition of individuals in control of the government may have preexisting economic stakes, the value of which depends on the ways financial rights are structured and enforced. Second, at the same time that the government is charged with enforcing loan contracts against debtors, it may need the political support of those same debtors. Third, the government not only plays a large number of supervisory, regulatory, and contract enforcement roles, it also looks to the financial system, and in particular the banks, to 
finance the state. That is, the government simultaneously regulates the banks and borrows from them. In short, conflicts of interest are baked into banking systems.

Making matters worse still, the government has multiple margins to behave opportunistically toward the banks in order to pursue its own goals. It can expropriate the banks outright; borrow from the banks and then renege on the loans; monetize its debt to the banks by printing money; raise reserve requirements and force the banks to hold those reserves in government bonds that yield negative real interest rates; or force banks to direct loans to government enterprises at below market interest rates. The government may also favor particular groups of bankers, depositors, or debtors because they are politically crucial. Examples of these actions by government include regulatory forbearance towards bankers, insuring depositors well beyond the statutory limits, directing banks to make loans to politically crucial constituencies, and forcing banks to forgive debts. In addition, the government may favor all of these groups - the bankers, minority shareholders, depositors, and debtors - through rescues and bailouts that come at the expense of taxpayers.

These inherent conflicts of interest among government actors imply that there are no fully "private" banking systems; rather, all modern banking systems represent a partnership between the government and a group of bankers. The basis of this partnership is simple: governments trade sets of valuable privileges that are embodied in bank charters in return for sources of finance that both fund the state and help maintain the existing political order. These sources of finance include purchases of government bonds (which may even be a requirement of the bank's charter), deposit reserves held by the central bank, government equity participation in the bank (with the equity paid for through a loan from the bank), and taxes on bank capital, earnings, or transactions. As part of the partnership, the government 
may also require that the banks allocate credit to groups that are politically crucial to the government, such as farmers, homeowners, or industrialists. In return, the bankers receive the charters necessary to operate banks.

The government charter is not just a license to conduct business: it represents a valuable concession. It grants the shareholders of the bank limited liability, allows the bank to hold government deposits, and gives the bank priority in the event of debtor insolvency. In fact, the government may decree that certain types of loans are only legally enforceable if they are made by a chartered bank. In the event that there is government deposit insurance, the government may also restrict coverage to deposits in a chartered bank. The fewer charters are granted, of course, the more valuable is each charter, and thus the larger the share of the resulting rents that the government can demand in exchange for the charter.

Government regulatory policies toward banks are not, therefore, created and enforced in order to maximize social welfare. Rather, they reflect the deals that gave rise to the partnerships among governments, bankers, and the interest groups that are crucial to the government. These deals determine which laws are passed, which groups of people have licenses to contract with whom, for what, and on what terms. Banks are regulated and supervised according to technical criteria, and banking contracts are enforced according to abstruse laws, but those criteria and laws are not created and enforced by robots programmed to maximize social welfare; they are the outcomes of a political process - a game as it werewith the stakes being wealth and power.

Calomiris and Haber refer to the process by which these government-banker partnerships are created as the "Game of Bank Bargains," and one of their insights is that the rules of play vary depending on a society's underlying political institutions. When a society's 
institutions do not limit the authority and discretion of government officials, through, for example, strong systems of checks and balances, the government can induce bankers to deploy their capital in a bank by structuring a deal that raises bankers' rate of return high enough to compensate them for the probability that the government will break its promises later. Similarly, minority shareholders must be compensated by high rates of return on capital in order to induce them to purchase shares in the bank, because there is no guarantee that the government will protect them from fraud or tunneling by the bankers if it is not politically convenient to do so. The most direct way that rates of return for both groups can be increased is simply to constrain the number of bank charters. The implication is that, under autocracy, the "partnership" between government and bankers will cause the banking system to strongly depart from any notion of allocative efficiency. Competition will be limited by the need to generate the rents necessary to induce investment. The system will be small and inherently prone to crises: periodically, the bankers will expropriate the minority shareholders and the depositors; and periodically, the government will expropriate everyone.

One of the insights of Calomiris and Haber is that when the risk of expropriation is high, government-created "safety nets" may also be used to entice bankers and minority shareholders to play the Game of Bank Bargains. These safety nets not only include limited liability for shareholders, but may also include extremely generous deposit insurance, government-run resolution authorities, and taxpayer-financed rescues of distressed banks. Such safety nets can be thought of as a substitute for capital for the purposes of getting deposits into the banks. When expropriation risk makes paid-in capital costly, the optimal bargain may favor a safety net as part of the bargain between the government and the bankers. The problem, from the point of view of the government, is that this variant of the 
Game of Bank Bargains has built-in incentives for moral hazard. The creation of a safety net puts the government in a vulnerable position: should the banking system fail, taxpayers and voters will hold it, and not the bankers, accountable — and that accountability may cost the government its hold on power. In this variant of the game, the parties in control of the government therefore need to be careful in choosing their banker-partners.

\section{Implications for Mexico's Game of Bank Bargains}

As we shall soon see, the way that the game of bank bargains was played by the government and Mexico's bankers from the 1970s onwards meant that, circa 1997, finding domestic partners had become problematic for the parties in control of the Mexican government. In the decade leading up to 1982, the government had become increasingly opportunistic vis-a-vis its banker partners by unilaterally altering the terms of the partnership. It then broke the partnership in 1982 by expropriating the bankers outright. Only nine years later, it sought to sell those same banks back to the private sector-and it sought to maximize the price at auction — but the memory of the 1982 expropriation was still fresh in the minds of

the potential buyers. In the negotiations between the government and the bankers, therefore, a deal was crafted in which the government was able to maximize the price it received, while the buyers put up little of their own capital and the government erected a generous safety net. That is, the government succeeded in forging a new partnership with a group of bankers, but the terms of the deal meant that the bankers had very little to lose if something went wrong, while the government had a tremendous amount to lose. This perverse alignment of incentives produced reckless lending from 1992 to 1995, which resulted in the banking crisis of 1995-96. The cost to the PRI of this failed partnership was immense: for the first time in its history, it lost control of the Chamber of Deputies in the 1997 midterm elections. Three 
years later, it lost the presidency.

When the government of Ernesto Zedillo thought about how to craft a stable partnership after rescuing the banks in 1995-96, it was therefore very cautious when it came to choosing its partners, lest it be politically exposed again. Rather than choosing to partner with domestic financiers, the Zedillo government chose a set of large, foreign-owned banks. From the point of view of the Zedillo government, foreign partners had four advantages: 1) they could be counted on recapitalize the banks with real (not fictitious) capital; 2) they did not own downstream non-financial enterprises that they be induced to save during a crisis by tunneling funds from their own banks; 3) they could not reasonably expect to be bailed out by the government in the event of a crisis; and 4) their managements might be concerned about not running afoul of regulators and stockholders in their home countries. In short, foreign bankers had a lot to lose if they mismanaged their end of the partnership.

The partnership between the Mexican government and foreign bankers also gained strength from the fact that the Mexican government could not easily expropriate foreign banks or otherwise reduce their property rights. Foreign bankers in Mexico, especially those from the United States and Canada, knew that they could access protection against the Mexican government from their home governments, as well as from international tribunals under NAFTA. Article 1110(1) of NAFTA is quite explicit on this point: "No Party may directly or indirectly nationalize or expropriate an investment of another Party ... or take a measure tantamount to nationalization or expropriation ... except: (a) for a public purpose; (b) on a nondiscriminatory basis; (c) in accordance with due process of law ... and (d) in payment of compensation." Article 1139 extends this guarantee against expropriation to all "property, tangible or intangible, acquired in the expectation or used for the purpose of economic benefit 
or other business purpose." NAFTA also creates international institutions with the authority to sanction signatory governments that violate its terms. Investors who believe that Mexican government has violated the terms of the NAFTA may demand compensation and have their case judged by a NAFTA tribunal. Moreover, they can go before a NAFTA tribunal to appeal judicial decisions made in Mexico that they consider to be against national or international law. The decisions of NAFTA tribunals can be appealed to national courts but only in the country where the case is brought. This means that Mexico cannot use its court system to overturn summarily the decisions of a NAFTA tribunal. If it did so, thereby violating the provisions of NAFTA, the other signatory governments could impose trade sanctions. (Condon and Sinha 2003: 127-129). In short, foreign bankers knew they had protections against the Mexican government that Mexican bankers did not have. Those protections meant that the Mexican government had a great deal to lose if it mismanaged its end of the partnership.

The result, as we shall see in the pages that follow, has been an impressively stable banking system. Indeed, while the United States, Great Britain, and Spain all suffered devastating banking crises in 2007-09, the banks from those countries that operate in Mexico continued to lend prudently and posted positive rates of return. 


\section{Section Four}

\section{Mexico's Uneasy Banking Partnership, 1920-1996}

It is not possible to understand why the Mexican government opened the banking system to foreign entry in 1997, without first understanding the events that led up to that decision. We therefore begin by presenting a brief history of the uneasy partnership between the government and Mexico's bankers from the end of the Revolution through the bank expropriation of 1982, the privatization of 1991-92, and the collapse and rescue of the banking system in 1995-96.

Though we do not want to short-change the details-indeed, we think they are crucial—we wish to highlight three facts. First, circa 1995-96, the majority of Mexico’s banks, especially its largest, were insolvent. Second, that insolvency was the outcome of the deals made during the process of bank privatization in 1991-92. Those deals reflected the difficulty of forging a partnership between the PRI and the bankers, given the opportunistic behavior of the government toward the bankers over the course of the previous two decades. Third, the insolvency of the banking system came at a tremendous political cost to the PRI. The Mexican public was outraged that the 1995-96 banking crisis had wiped out much of their wealth and that they, through the tax system, were paying for its resolution. Indeed, the political fallout from the rescue undermined the PRI's legitimacy and was decisive in shifting voter support to the PRD and PAN in the 1997 elections. Surveys indicate that as of 1997 voters no longer believed that the PRI was a more capable steward of the economy than the political opposition (Magaloni 2006: Chap. 7). 


\section{Tenuous at the Origin}

The origins of the modern Mexican banking system go back to the Porfiriato. Indeed, some of the largest banks in Mexico today, most particularly Banamex and Santander Serfin, trace their origins to this period. We cannot hope to do justice to the voluminous literature on this pre-revolutionary banking system. We can, however, point to three salient features of it. First, by the standards of post-revolutionary Mexico it was quite sizable. Maurer (2002: 91), estimates gross credit from commercial banks at 25 percent of GDP in 1910. The ratio of total commercial and mortgage bank assets to GDP was 38 percent, roughly the same level as today (Maurer and Haber 2007). Second, it was extraordinarily stable (Maurer and Haber 2007). Third, it was based on a partnership between a group of well-connected financiers and the government of Porfirio Díaz: in exchange for loans (both to the federal government and state governments), Mexico’s bankers were awarded highly profitable segmented oligopolies. ${ }^{3}$

Every side during the Mexican Revolution then preyed upon this banking system in order to finance their military campaigns. One of the ironies of the Mexican Revolution was that the two figures who were the most closely identified with business interests, Victoriano Huerta and Venustiano Carranza, were the most aggressive predators against the banks. By 1918, Mexico barely had a banking system: virtually all of the Díaz-era banks had been dissolved, save Banamex and the BLM, and those banks had been stripped of most of their assets (Maurer 2002).

3 Some salient works in this literature include: Ludlow and Marichal (1985); Maurer (2002); Cerutti and Marichal (2003); Haber, Razo, and Maurer (2003); Maurer and Gomberg (2004); Maurer and Haber (2007). 
The lack of a functioning banking system jeopardized the survival of Mexico's postrevolutionary governments. In fact, calling them governments implies a good deal more stability and institutionalization than actually existed. The Mexican political system in the 1920s was little more than a fragile coalition of warlords allied to corrupt labor leaders, and headed by two political-military strongmen who had been part of the Carrancista movement, Alvaro Obregón and Plutarco Elias Calles. The Obregón-Calles regime faced several threats to its survival, including two attempted military coups, an armed rebellion led by the Secretary of the Treasury, and a church-state civil war. Obregón and Calles tried to obtain the revenues they needed to fight those movements by increasing taxation on mining and petroleum, but failed at both. (Haber, Razo, and Maurer, 2003). This meant that they had strong incentives to create a banking system from which they could borrow. At the same time, the private sector — most importantly the country's manufacturers—was clamoring for the creation of a banking system that it could use to finance its operations. Given the fact that Obregón and Calles were trying to hold together a fragile coalition, and that a crucial part of that coalition - which even provided paramilitary support - was the country's newly unionized industrial workers, keeping the factories operating was as important as finding a source of public finance.

There were several failed attempts by Obregón to rekindle the banking system in the early 1920s, but these fizzled because Obregón soon reneged on whatever promises he made to the bankers. (Haber, Razo, and Maurer 2003). Obregón and Calles, therefore, went back to the drawing board to come up with a plan to coax the country's private financiers into deploying their capital in a banking system from which the government could borrow. In order to do so, they gave the bankers considerable say in the system's design. In late 1924, 
Secretary of the Treasury Alberto Pani called a special convention of government officials and bankers, some of whom had been major figures in the pre-revolutionary banking system. That is, the government quite explicitly signaled that it wanted to form a partnership.

The laws that were crafted at the 1924-25 convention were designed to give the bankers incentives to deploy their capital by raising rates of return through the creation of barriers to entry. First, all pre-existing banks were grandfathered in. Second, the incumbent bankers were appointed to a newly-created National Banking Commission, giving them considerable influence to block the entry of new banks, as well as to influence other aspects of banking and credit policy. Third, in order to make it difficult for other banks to enter the market, the minimum capital requirement was set at 500,000 pesos (roughly $\$ 250,000$ ), and was made higher still for banks that wished to operate a branch or office in Mexico City, where the minimum capital was set at one million pesos $(\$ 500,000)$. Fourth, obtaining a bank charter required the specific approval of the Finance Secretary and the President. Fifth, the convention established a new commercial bank, the Banco de México (Banxico), whose shares were owned both by private banks and by the government. The purpose of Banxico was three-fold: to serve as the treasury's fiscal agent; to rediscount notes from shareholder banks; and to advance credit to business enterprises. (Haber, Razo, and Maurer, 2003).

Banxico grew out of a political bargain among Mexico's leading bankers and politicians. The bankers worried about expropriation via forced lending or selective defaults. Banxico was therefore granted a monopoly on government lending so that the government could not default on loans to some bankers while borrowing more money from others. If the government abrogated one bank's property rights, it would be abrogating all banks' property 
rights, because they all held stock in Banxico. Safety in numbers meant that collective risk was lower risk.

Although this deal was far from ironclad, it did succeed in coaxing some capital back into the banking system. We should be clear, however, that the resulting banking system was miniscule when compared to what had existed prior to the Revolution. If we leave out Banxico, which mostly lent to the government, as well as business enterprises owned by members of the government, the ratio of private credit to GDP from the commercial banks was only four percent in 1925 and five percent in 1929, which was roughly one-quarter to one-third the level in 1910 (See Figure 2).

Mexico's bankers had good reason to be wary, because they soon had to contend with a party-based dictatorship. In 1929, in the wake of Obregón’s murder, Calles organized Mexico’s remaining military leaders into a political party, the Partido Nacional Revolucionario (PNR). A series of reforms in the 1930s integrated Mexico's organized labor movement and peasant confederation into the structure of this party, creating the PRM. In the 1940s, the PRM was further reformed, giving rise to the PRI.

As soon as this party-based dictatorship started to take shape in the 1930s the government began to claw back some of the policy-making authority that the Obregón-Calles regime had delegated to private bankers. In 1932, the government converted Banxico into a central bank. A further reform in 1936 required commercial banks to maintain cash reserves in Banxico, which is to say that banks had to lend part of their deposit base to the government. That same law also transferred many bank supervisory functions from the banker-influenced National Banking Commission to Banxico. In a further set of reforms enacted in 1941, the 
government forced commercial banks to divest their investment banking operations into separate corporations, called Financieras. (Del Angel Mobarak, 2002, 2005).

These reforms to bank regulation took place amidst outright expropriations in other areas of the economy. Industrialists had been threatened with expropriation when they tried to curtail operations during the Great Depression of the 1930s. The Cárdenas administration had seized foreign-owned petroleum companies in 1938, and in that same year the government expropriated the country's largest paper mill so that it could fully control access to newsprint. Commercial farmers, of course, had been subject to expropriation ever since the revolution, and they had seen many of their best lands taken over during the Cárdenas presidency. (Haber, Razo, and Maurer 2003).

Once the government began to renegotiate the deal that had been forged in 1924-25, Mexico's financiers began to pull back. As Figure Two shows, the banking system, miniscule as it was, actually began to shrink; credit from commercial banks fell from seven percent of GDP in 1933 to three percent of GDP by 1939, even though demand for credit was increasing because the Mexican economy grew at a brisk pace during the late 1930s. Commercial bank credit would remain at depressed levels for the next 40 years. This pattern even holds if we include credit from the financieras, which bumped up the amount of total private credit from privately-owned banks by only a trivial amount until the 1960s. In fact, the peak level of combined commercial bank and financiera lending was only 17 percent of GDP, and that level 
was not reached until 1972. That is to say, during the period 1925 to 1978 , the amount of credit issued by private banks (relative to GDP) likely never exceeded its 1910 levels. ${ }^{4}$

The pervasive distrust of the government by Mexico's leading financiers presented the PRI with a problem: the party needed an alternative to private banks as a means to support a growing economy in order to sustain its hold on power. To solve that problem, the PRI created a broad array of government-owned development banks. The first of these had been founded in the 1920 s to provide credit to agriculture - as well as to provide loans to revolutionary generals turned landowners-but in the 1930s and 1940s government-owned banks mushroomed, and they were increasingly used to provide long-term finance for Mexico's growing manufacturing sector. As Figure Two shows, by the 1950s, credit from development banks exceeded credit from commercial banks and financieras combined. Indeed, by the 1970s, credit from the government-owned development banks so dwarfed credit from commercial banks and financieras that the government allowed these privatelyowned banks to merge, creating enterprises called multi-banks.

In theory, government development banks were supposed to provide credit to small and medium-sized enterprises, in order to level the playing field against the large industrial conglomerates that mobilized credit from the commercial banks and financieras. Mexico's industrial conglomerates typically owned both a commercial bank and a financiera, and the portfolios of those banks tended to be composed of shares held in the enterprises that were part of the conglomerates. (Del Angel Mobarak, 2002). The commercial banks and financieras

${ }^{4}$ We assume that the Díaz-era commercial banks had a fairly standard loan-assets ratio of roughly 50 percent, an assumption that squares with what we know about the composition of their balance sheets. Thus, their ratio of assets to GDP of 32 percent in 1910 would translate into a loan to GDP ratio of 16 percent. Data from Maurer and Haber (2007). 
were, in essence, the treasury divisions of the conglomerates. As a practical matter, however, the government-owned development banks tended to allocate most of their credit to the very same industrial conglomerates that received financing from the privately-owned banking system. The political pressure to lend to large firms, which tended to have large, unionized, and politically influential labor forces, simply outweighed whatever original mandate the development banks may have had. This meant that industrial and commercial conglomerates could fund risky enterprises through the development banks rather than from the private banks that were under their control. (Cárdenas, 2000: 190, 195).

The commercial banks, financieras, and development banks therefore all worked together to finance Mexico's largest industrial and commercial enterprises. The development banks tended to serve as second tier lenders, repurchasing loans made by commercial banks through special programs designed to channel credit to sectors that the government deemed crucial. In fact, the credit law of 1941 actually required commercial banks to allocate 60 percent of their loans to such directed credit programs. (Del Angel Mobarak, 2002). These directed-credit programs represented a government guarantee to the banks because all of the default risk was born by the development bank. Not surprising, as Del Angel Mobarak (2002) has shown, Mexico’s commercial banking system was stable and profitable.

For all its "stability," however, the bottom line was a system that encouraged reckless behavior: shareholders and depositors in commercial banks and financieras did not bear the risk of loans gone bad; rather, the risk was borne by taxpayers who ultimately subsidized the development banks. Not only did the development banks serve as second tier lenders, thereby taking risky loans off of the balance sheets of the commercial banks, development banks also made direct loans to private manufacturers, further subsidizing large industrial firms as well 
as the private banks that were affiliated with them. The largest development bank, Nacional Financiera (NAFIN), founded in 1934, obtained its capital by selling government-guaranteed bonds and then made long-term loans to manufacturers that were collateralized by blocks of shares issued by those firms. NAFIN was supposed to provide credit to small and mid-sized

manufacturing companies, which were often unable to obtain financing from commercial and financieras. As a practical matter, however, NAFIN allocated most of its credit to the very same industrial conglomerates that received financing from private banks. (Cárdenas 2000: 190). Worse, because of the political importance of their workforces, the government came to use NAFIN as a mechanism to bail out manufacturers that were not economically viable. Even worse, the policy of bailouts encouraged moral hazard: knowing that they would be bailed out, manufacturers undertook high-risk activities of doubtful expected profitability. (Cárdenas, 2000:195.) The end result was that the Mexican government, which is to say Mexican taxpayers, came to own a wide range of commercial and industrial enterprises of dubious value, including sugar refiners, steel mills, mining companies, railroads, airlines, and hotels. In 1970 there were 85 state-owned firms. By 1976 there were 740. In 1982 there were 1,155. (Valdés Ugalde, 1994; Cárdenas 2000: 195; Smith 1991: 371).

\section{Ending the Partnership: The Bank Expropriation of 1982}

The partnership between Mexico's bankers and the PRI was always fragile. It was based on the fact that the bankers and the manufacturers were one-and-the-same, that the PRI needed to reward organized labor for its political support; and that those organized workers were employed by the same industrial conglomerates that were owned by the bankers. The 
implication is that if the political calculus of the PRI leadership changed, there was little that the bankers could do to protect themselves against expropriation.

The change in calculus occurred in the 1970s, as government expenditures began to outstrip revenues by a wide margin — and it resulted in the unwinding of the partnership. During the 1950s, the Mexican government had run balanced budgets; the fiscal deficit was typically on the order of 0.1 percent of GDP. In the 1960s, however, it began to spend at a rate that outpaced growth in its revenues: deficits began to escalate, averaging 1.9 percent of GDP across the decade. The situation worsened during the 1970s; the fiscal deficit averaged 6.6 percent of GDP. By 1981, the deficit was a staggering 14 percent of the GDP. (Bazdresch and Levy, 1991: 249).

Unwilling to bear the political costs of raising taxes or cutting expenditures, the government directed the central bank to expand the money supply, which had the predictable effect of raising the rate of inflation. The average annual rate of inflation in Mexico accelerated from 2.7 percent in the 1960 s to 16.8 percent during the 1970 s. By 1981 , it hit 27.9 percent. The Mexican government was, in short, financing its deficits through an inflation tax.

Inflation taxes can, of course, be shared with commercial banks. In fact, the inflation tax was a considerable source of profits for Brazilian commercial banks in the 1960s and 1970s. (Lees, Botts, and Cysne, 1991). An inflation tax is essentially, the amount of real interest earned by the monetary authorities on the stock of M1. This stock of M1 earns zero nominal interest. Some of M1, of course, is held by commercial banks in the form of demand deposits. Thus, if the deposit reserve requirement of the central bank is set at zero, all revenues from the inflation tax earned on demand deposits accrue to the commercial banks, 
and all revenues from the inflation tax on cash accrue to the government. This situation, of course, rarely happens; governments typically want to garner revenues from the inflation tax on demand deposits, and therefore typically increase deposit reserve requirements when they are running an inflation tax..$^{5}$

There was not much sharing of the inflation tax with commercial banks in Mexico. Echeverría and López Portillo dramatically raised bank reserve requirements. Reserve ratios climbed from just three percent of deposits in 1959 to 46 percent by 1979. (IMF, International Financial Statistics Database). The central bank paid interest on those reserves, but that interest rate was below the rate of inflation. In addition, the government established interest rate ceilings. (Del Angel Mobarak 2002: 285). Inasmuch as a the Banco de México held a large proportion of private banks' deposits, earning interest rates lower than those available on alternative investments, and banks could only make private loans subject to interest rate caps, the banks responded by offering interest rates on deposits that were lower than the prevailing rate of inflation. As a result, depositors began to withdraw their money from the banking system. The ratio of bank deposits to GDP had been climbing, growing from 17 percent in 1960 to 29 percent by 1969 . The inflation tax caused disintermediation: by 1979 , the ratio of deposits to GDP had fallen back to 24 percent (World Bank, Financial Structure Database, November 2010 update).

The combination of falling deposits and increased lending to the government (through higher reserve requirements) had a predictable effect: The supply of bank credit for private purposes declined dramatically. As Figure 2 shows, the ratio of credit from commercial banks

${ }^{5}$ This sharing of the inflation tax between the government and the banks on demand deposits can be thought of as the real interest earned by the banks on demand deposits minus the real interest on total reserve requirements they have to pay the monetary authorities. 
and financieras, relative to GDP, had reached 17 percent in 1970. By 1977, it had fallen to only 11 percent. At this point, Mexico's bankers began to express concern that they were going to be expropriated. (Del Angel Mobarak and Martinelli Montoya 2009: 21).

The situation facing bankers turned worse in the early 1980s. In addition to printing money to fund escalating deficits, López Portillo borrowed heavily abroad, believing that a combination of rising petroleum prices and discoveries of new reserves in the Gulf of Mexico would allow him to service the growing debt. When the price of oil collapsed, beginning in early 1982, López Portillo had to scramble to avoid a foreign debt default. He converted U.S. dollar-denominated savings accounts into pesos at the official rate of exchange (which was approximately one-third less than the rate on the parallel exchange market), thereby expropriating the assets of individuals and firms holding dollar accounts. When that proved insufficient, he declared that the government was temporarily suspending payments on Mexico's foreign debt, a step that only accelerated the run on the peso.

Citizens and business enterprises responded by converting their peso assets to dollars, which they then moved out of the country partly aided by commercial banks. López Portillo responded by blaming the bankers for the collapse of the exchange rate, and expropriated the banks on September 1, 1982 with the stroke of a pen; the expropriation, which required a constitutional amendment, was ratified by the Mexican congress with virtually no debate. (Del Angel Mobarak, 2005). ${ }^{6}$ The bankers received compensation in the form of government bonds, but these were of dubious value; after all, the government had already stopped payment on its foreign debt and the country was entering a hyperinflation.

\footnotetext{
${ }^{6}$ Del Angel Mobarak and Martinelli Montoya (2009) develop a game-theoretic model in which the government saw the end of its partnership with bankers when the bankers aided in the speculation against the peso. In their model, the government had to pursue expropriation in order to show that its threats were credible.
} 
For the next seven years, Mexico's banks continued to take deposits and clear checks, but they directed more than half of their lending to public-sector loans to fund government budget deficits. As a consequence, firms and households were starved for credit. By 1988 the ratio of private-sector loans to GDP was only 8 percent. (IMF, International Financial Statistics Database). Worse, much of that private credit was directed to politically-crucial producer and consumer groups based on criteria other than economic viability. Thus, in the late 1980s the ratio of non-performing to total loans began to climb markedly. That is, the government may have owned the banks, but those banks were becoming increasingly unprofitable. (Gunther, Moore, and Short, 1996).

\section{How Do You Sell Something that You Just Stole?}

The Mexican economy limped along for the next several years, the government simultaneously trying to fight an inflation rate that sometimes exceeded 100 percent, growing unemployment, and the national private sector's fundamental lack of confidence in the PRI. President López Portillo's successor, Miguel de la Madrid Hurtado (1982-88), did what he could, but what he could was limited by a fundamental fact: the Mexican government had been growing beyond its means for close to two decades. President de la Madrid could neither raise taxes effectively, nor borrow abroad, to finance these deficits. He therefore focused on cutting spending, and opening up the economy to foreign trade.

When President Carlos Salinas de Gortari came to office in 1988 he therefore still faced a hyper-inflation, a slow growing economy, a massive public sector debt, and thousands of poorly performing state-owned enterprises. He also headed a party that was rapidly losing legitimacy. Indeed, his election produced the smallest margin in the history of the PRI, and 
even that outcome was widely asserted to be the product of fraud. ${ }^{7}$ This last fact cannot be stressed strongly enough. Salinas was not just charged with getting the economy back on track; the fate of the PRI rested in his hands.

Salinas' solution to these overlapping fiscal and political challenges was to sell off state-owned enterprises. Their sale not only provided the government with extraordinary revenues that it used to pay down the public debt, but it also reduced the drain that those (perennially unprofitable) firms put on the annual budget, thereby helping to bring inflation under control. The sale of state-owned enterprises also provided the Salinas government with one-time revenues that could be used as partial funding for the social programs that were a crucial part of the PRI's strategy to win the 1994 presidential elections and reestablish its political dominance. (Magaloni, 2006).

The combination of these fiscal and political considerations meant that the Salinas government sought to sell the banks in as short a time period as possible and maximize the revenues from that sale. The result was that the process of bank privatization was accomplished in just 18 months. It also meant that the government earned $\$ 12.4$ billion dollars from the sale - three times the book value of the banks.

${ }^{7}$ When federal electoral officials began counting ballots on the evening of July 6 , 1988, the early returns (principally from Mexico City and the surrounding area, where antiPRI opposition was strongest) put opposition candidate Cuauhtémoc Cárdenas in the lead. Vote tallies arriving later from other parts of the country favored the PRI, but Ministry of the Interior officials feared the worst, panicked, and claimed that a computer failure prevented them from releasing preliminary results. The PRI then claimed victory for Salinas. When the Federal Electoral Commission announced official results a week later, it declared Salinas the winner. 


\section{Bank Privatization Amidst Expropriation Risk}

Why, one might ask, would investors pay high three times book value for banks that the government had seized only nine years before? Why wouldn't they have offered a low price, to compensate them for the risk that the government might just expropriate them all over again?

Mexico's bankers had good reason to harbor these fears. President Salinas might have been pro-business, but there was no telling what his successors might want to do, and there were few checks on presidential power. The Mexican president could, as a practical matter, reduce property rights at will. Moreover, the Mexican government, as the bankers well knew, did not have to engage in de jure expropriation. It had a broad range of methods by which it could carry out a de facto expropriation, all of which it had used in the 1970s: increase deposit reserve requirements; finance deficits by increasing the money supply, thereby setting off an inflation that would essentially be a tax on the holders of cash; or impose interest rate ceilings, driving profit margins to zero.

Forging a partnership between the Salinas government and Mexico’s bankers was not, therefore, an easy process. The government wanted to sell something that it had expropriated only nine years before, and it wanted to maximize the price it received. The bankers wanted the banks back, but as a general rule, bankers who face expropriation risk do not pay price premiums for banks. Nevertheless, the incentives of the government and the bankers were aligned through a deal that minimized the amount of capital that the bankers had at risk. This deal was not created in a single stroke. Rather, it emerged over time, out of the interaction of the government and the bankers during the process of privatization and afterwards: each discrete decision or agreement driving the next decision or agreement. The outcome of this 
game, however, was a banking system in which the group that had the most at risk-Mexico's taxpayers (who would have to fund the deposit insurance system in the event of bank insolvency) — had no active voice in the game as it was being played.

The key to the government-banker partnership was that the bankers did not have to put much of their own capital at risk. How they did this warrants a prolonged discussion about the technical process of the bank auction and manner in which the auction winners were able to pay for the banks, but before we get too far into the details we wish to stress that, as a conceptual matter, the deal that was crafted ultimately amounted to an agreement to shift liability to Mexican taxpayers in the event that the partnership proved to be unprofitable for the bankers. That is, bankers entered into a partnership with the government, limiting their liability and the limiting the amount of capital they put at risk. In return, the government received a large, one-time infusion of cash. In order to induce firms and households to deposit funds into this under-capitalized system, the government erected a very generous safety net: deposit insurance was unlimited. The government was, in essence, saying that if something went wrong, it assumed liability. As we shall see, when the partnership collapsed and bill came due, Mexico's taxpayers blamed the government of Carlos Salinas.

\section{The Auction Process}

Let us then start with the auction process itself. In structuring the auction, the government signaled bidders that they would not have to operate in a competitive environment. The Mexican banking industry at the time of privatization in 1991 was composed of 18 banks, four of which controlled 70 percent of total bank assets. The government did not break these up, but sold them as is. The government also signaled potential bidders that they would not have to compete against foreign banks. Foreign banks 
were not allowed to participate in the 1991-92 bank auctions. They had also already been effectively excluded from the Mexican market during the negotiations over NAFTA. ${ }^{8}$ The government was, in effect, selling the rights to operate an oligopoly. ${ }^{9}$

At the same time that the government signaled bankers that they were purchasing secure oligopolies, it structured the auction process so as to maximize the prices on offer. The formal rules of the auction specified that bids would be sealed and that the managerial expertise of the bidding groups would be taken into account. (Unal and Navarro 1999). The notion that the government would take the quality of management into account was, however, eviscerated by a decision to only do so if the second highest bid was within three percent of the first highest.

${ }^{8}$ The provisions governing banking in the 1994 NAFTA agreement severely limited the participation of foreign banks in Mexico. NAFTA provided that U.S. and Canadian banks could own no more than $30 \%$ of a Mexican bank's capital. It also provided that U.S. and Canadian banks could not purchase a controlling interest in any Mexican bank whose market share exceeded 1.5 percent and that the total market share under their control could not exceed eight percent. This restriction meant that foreign banks were effectively excluded from the market, because there were only two banks with market shares of 1.5 percent or less. Over a six-year transitional period U.S. and Canadian banks could gradually hold larger market shares, up to a maximum of 15 percent by the year 2000. Even after this transitional period, however, NAFTA allowed the Mexican government the right to freeze the purchases of Mexican banks by U.S. and Canadian concerns for a three-year period if foreign banks as a group controlled more than 25 percent of the market. Foreign banks were also still subject to the rule that they could own no more than 30 percent of a Mexican bank's stock. (Murillo 2005).

${ }^{9}$ There exists some debate in the literature as to whether Salinas insisted on excluding foreign banks from the market, both during the NAFTA negotiations and during the privatization, because he sought to signal that he was selling a secure oligopoly (e.g. Haber 2005), or because he had sound economic reasons for believiing that the payments system must be in the hands of Mexican bankers (e.g., Suárez Dávila 2010). Regardless of Salinas's intentions, from the point of view of Mexico's bankers, the exclusion of foreign banks from the market would have caused them to bid more aggressively; they knew that foreign entrants could not reduce their market power. 
Consistent with its goal of maximizing prices on offer, the government also did not bring Mexico's accounting standards in line with generally accepted accounting standards. One of the most lenient of Mexico's bank accounting rules was that when a loan was past due, only the interest in arrears was counted as non-performing. The principal of such loans could be rolled over, and counted as a performing asset. Moreover, the past due interest could be rolled into the principal and the capitalized interest could be recorded as income. Reforming this rule (as well as others that inflated bank capital and assets) would have lowered the market value of the banks, because it would have increased the ratio of non-performing to total loans, lowered the banks' reported rates of return, and decreased the book value of assets (Del Angel Mobarak, Haber, and Musacchio 2006). How much lower the banks would have been valued is difficult to know. It is known, however, that the government contracted outside consulting firms to provide it with a valuation of the banks. It did not, however, make the results of those studies public. (Unal and Navarro, 1999).

The bankers were not, therefore, able to conduct a detailed analysis of the quality of the assets prior to the auction. They were promised, instead, that after they purchased the banks they could receive reimbursements from the government for assets that were not properly valued. There is evidence, however, that the government did not honor this promise. Indeed, bankers who participated in the auctions report that the government refused to reimburse them for assets that were non-performing. One prominent banker went so far as to say that the auction process therefore amounted to being asked to bid on a house by only looking at it from the outside with the doors and windows shut tight. (Espinosa Rugarcía and Cárdenas Sánchez, 2011, Vol 3: 55, 73). 
The government then auctioned the banks sequentially. Rather than a single round of sealed bids, the government sold the banks in six rounds of bidding between June 1991 and July 1992. This increased competition for the banks in the later rounds, thus creating a "cascade effect." As Table 2 shows, the most important determinant of the price paid for a bank (in terms of its bid-to-book ratio) was the bidding round in which it was purchased. All things being equal (size of bank, profitability, number of bidders) each additional round of bidding pushed up the bid-to-book ratio by .30 . This ratio is stable across alternative specifications and is always significant at the one percent level. In fact, bidding round is the only statistically significant variable that has a positive sign in the regressions. Surprisingly, neither the rate of return on assets, the rate of return on equity, nor the number of bidders is statistically significant. ${ }^{10}$ Perhaps most surprisingly, the market power of a bank (measured as the log of bank assets) is statistically significant, but it has the wrong sign: market power is negatively correlated with the bid to book ratio. This is not the outcome that one would expect from theory: one would usually expect that the market power of a bank would be capitalized in its auction price. ${ }^{11}$

${ }^{10} \mathrm{We}$ measure profitability as both the rate of return on assets and the rate of return on equity over the three years prior to the auction.

11 One might argue that the positive correlation between the bid-to-book ratio and the bidding round is an artifact of the way we measure the bidding variable (a single variable with a range of 1-6, corresponding to each bidding round). We therefore re-estimated the regressions measuring bidding round as a series of dummy variables. The results are consistent with the results in Table 2. We therefore do not reproduce them here. 
This set of institutional arrangements produced an average (weighted) bid-to-book ratio of 3.04, and an income of $\$ 12.4$ billion for the Mexican government. ${ }^{12}$ Indeed, bid-tobook ratios of 3.04 suggest that the government received a substantial premium. In United States bank mergers during the 1980s, for example, the average bid-to-book ratio was 1.89 (Unal and Navarro, 1999: 78). Mexico’s bid-to-book ratios were also high by European standards: in European bank privatizations the typical bid-to-book ratio was on the order of 2.5 - and European bankers did not face the same expropriation and default risk as did Mexican bankers. Moreover, research by Gunther, Moore, and Short (1996) indicates that the share of past due loans, the return on banking assets, and the industry's capital to asset ratio were all moving in a direction indicating increasing weakness among Mexico's governmentowned banks, even before they were auctioned. An analysis by Unal and Navarro (1999) of the market value of traded shares around the time of the auction is consistent with the Gunther, Moore, and Short view: the prices paid at auction carried a premium of 45 percent over the value of that equity as priced by the Mexican stock market.

\section{Weak Monitoring, Reckless Lending}

Reckless behavior by banks is typically prevented by monitoring by three groups: bank shareholders (who operate through directors), bank depositors, and government supervisors. If the first two groups have substantial money at risk, government supervision is superfluous. Indeed, most of the world's banking systems ran without much in the way of government supervision until the mid $20^{\text {th }}$ century. The weaker are the incentives of

${ }^{12}$ A bid to book ratio of 3.53 is commonly cited in the literature. This is the unweighted average. But, Mexico's largest banks actually received lower multiples of their book value when they were auctioned than the smaller banks. 
shareholders and depositors to monitor the bankers, however, the more crucial is the role of government supervisors.

The shareholders of Mexico's banks did not, however, have very much capital at risk. They therefore were weak monitors. Their lack of risk was an outcome of the payment plan that the bankers had brokered with the government. The original payment plan devised by the government called for a 30 percent payment three days after the announcement of the auction winner, with the remaining 70 percent due in 30 days. The winners of the auctions, which is to say that majority shareholders who were to become the directors, convinced the government, however, to replace those rules with one that gave them time to finance their purchases with outside sources of funds. Under the new plan, the first payment was reduced to $20 \%$, a second payment of $20 \%$ was to be paid 30 days later, and the remaining $60 \%$ was to be paid four months after that. They then used the five-month period between the auction and the final payment to raise the funds to purchase the banks from outside investors. (Unal and Navarro, 1999). These funds came from a variety of sources - small Mexican investors, commercial paper, foreign banks, other Mexican banks, and in some cases, the same bank that had been purchased. That is, shareholders were able to finance or refinance their share purchases with a loan from the same bank they were purchasing, with the collateral for the loan being the shares that were being purchased. In the case of Bancomer, which was the largest bank in the system, 20 percent of the first payment made to the government by the winning bidders was actually financed by a loan to the bidders from that same bank, a fact that its pre-1982 owner characterized as "monstrous." (Espinosa Rugarcía and Cárdenas Sánchez, 2011, Vol 3: 11-12). In another case, a group of purchasers actually financed 75 
percent of the total cost of acquiring a bank through a loan from that same bank. (Mackey 1999: 55, 61, 141, 216). ${ }^{13}$

The lack of effective monitoring by majority shareholders meant, of course, that Mexico's depositors faced considerable risk. They were not sheep to be fleeced. Thus, the logic of the situation now required that they too be protected. As a technical matter, bank deposits in Mexico were insured by a Trust Fund (FOBAPROA), up to the available resources held by FOBAPROA. These resources were the premiums paid by banks, and were very limited. As a practical matter, however, FOBAPROA had the ability to borrow from the Banco de México. According to Mexico's Law of Credit Institutions, the Technical Committee of FOBAPROA (on which sat representatives from the Ministry of the Treasury, the National Banking Commission, and the Banco de México) made recommendations that were forwarded to the governor of the Banco de México, who then acted on behalf of the bank, in its capacity as FOBAPROA's fiduciary trustee and legal representative (Mackey 1999: 44).

The Banco de México’s guarantee, moreover, was not just implicit, as a consequence of its fiduciary relationship to FOBAPROA. It was an explicit promise. The Banco de México was supposed to publish, in December of each year, the maximum amount of obligations that would be protected by FOBAPROA during the following year. Instead, its

${ }^{13}$ In the case of Banca Serfin (Mexico's third largest) an additional departure from the usual procedures might also have reduced the director's capital at risk. Unlike its practice in all the other bank auctions, the government held back $16 \%$ of the stock from the bidding process. This remaining 16 percent was a purchasing option for the group that bought the bank that they could exercise after the auction process closed. (Unal and Navarro, 1999). 
1993 and 1994 statements did not actually list amounts, but provided the following blanket statement:

"Based on Section IV of Article 122 of the Law of Credit Institutions, and considering that it has been a tradition that the Mexican financial authorities try to protect investors from any loss in case of insolvency of Credit Institutions, the FOBAPROA's Technical Committee has decided to continue with such tradition, for this reason it has been agreed that FOBAPROA will endeavor to honor all of the liabilities charged to financial institutions that participate in the fund, provided that they are derived from their operations, excluding liabilities arising from subordinated debentures, liabilities resulting from illicit, irregular, or bad faith operations..." (As quoted in Mackey 1999: 53). ${ }^{14}$

The Banco de México explicitly stated that it was not only guaranteeing all deposits (including interbank deposits), it was also guaranteeing virtually all bank liabilities (deposits, loans, and credits) with the exception of subordinated debt. Making matters worse, there were no general guidelines regarding limitations and restrictions on the whole range of FOBAPROA programs. Rather, participation was to be determined on a case-by-case basis (Mackey 1999: 52). In short, the government signed a blank check in case catastrophe struck. This decision by the Banco de México eviscerated the incentives of depositors to monitor the banks. Precisely because there was unlimited deposit insurance, bank depositors did not police banks by withdrawing funds from banks with risky loan portfolios. Research by Martinez Peria and Schmukler (2001) that analyzes changes in time deposits and interest

${ }^{14}$ From 1995 to 1997, the statement was amended slightly, by adding the following phrase "and liabilities derived from loans granted between banking institutions participating in funds transfer systems administered by the Bank of Mexico, to back up obligations chargeable to the Bank of Mexico, as well as liabilities in favour of intermediaries belonging to the same financial group as the bank." (Mackey 1999: 53). 
rates in Mexico from 1991 to 1996 finds that various measures of banks' riskiness did not influence deposit growth through September 1995.

There is a well-known, inverse relationship between the extent of deposit insurance and the need for government supervision of banks: by reducing the incentives for depositors to monitor bank managers and directors, generous deposit insurance places a heavy burden on government supervision. It is rarely the case that government supervisors can monitor everything that goes on inside a bank, and thus generous deposit insurance is usually associated with unstable banking systems (Demirgüç-Kunt and Kane, 2002; Demirgüç-Kunt and Detragiache, 2002; Demirgüç-Kunt and Huizinga, 2004).

Making matters even worse, Mexico's supervisors were inexperienced and were equipped with only the bluntest of instruments. Bear in mind that during the 1980s, when the government ran the banks, there was little need for supervision, because most lending consisted of government bond purchases. Moreover, it was the government itself, seeking to maximize prices on offer, which had designed Mexico's extremely permissive bank accounting standards. Complicating the job of supervisors even further was the fact that, prior to 1995, the Comissión Nacional Bancaria (CNB) did not have sufficient information technologies on hand to actually gather information from the banks in a timely manner. It also lacked the authority and autonomy to properly supervise the banks (Mackey 1999: 97). Mexico's bankers may, in fact, have expected a high degree of regulatory forbearance. (Gruben and McComb 1997).

Mexico's bankers therefore faced an amazingly weak set of monitors. Little wonder, then, that they did not invest in internal systems of credit analysis. Indeed, as Mackey (1999:56) has pointed out, banks' internal credit systems were weak to the point of being non- 
existent. Making matters worse, reports drawn on borrowers from private credit reporting companies could not be used as a substitute for weak internal institutions. There was, in fact, virtually no private credit reporting in Mexico until 1995. (Negrin, 2000; Mackey 1999: 25).

\section{The Consequences of Weak Monitoring}

The lack of effective monitoring meant that the Mexican banking system quickly began to accumulate a large volume of non-performing loans. As Table 3 demonstrates, when we sum the value of declared non-performing loans (which only included past due interest) to the value of "rediscounts" (the rolled over principal of those non-performing loans), as early as December 1991 more than 13 percent of the loan portfolios of Mexico’s banks were nonperforming. By December 1993 the rate was over 16 percent.

Thus, the Mexican banking system was poised for collapse even before the peso devaluation of December 1994 (the so-called Tequila Crisis), which caused the central bank to raise interest rates and generated widespread default among borrowers with variable rate loans. Gonzalez-Hermosillo, Pazarbasioglu, and Billings (1997) have demonstrated this using a hazard model to predict bank failure after privatization through 1995 . Their results show that it was not the macroeconomic shock of the 1994-96 peso crisis that led to bank failure. Rather, that event served as a tipping point for banks that were fragile to begin with.

How the banking system came to this precarious situation is the subject of some debate. There is widespread agreement that the root cause was ineffective monitoring. There is not, however, agreement on whether ineffective monitoring allowed inexperienced and over-optimistic bankers to act in an imprudent manner or whether ineffective monitoring allowed bankers to engage in tunneling. The two hypotheses are not mutually exclusive: both could have been going on. 
The first view—-that bankers were inexperienced and overly-optimistic — stresses that the level of financial penetration in Mexico in 1991 was quite low by the standards of developed countries, and thus bankers perceived that there would be lucrative returns from entering the underserved Mexican market. (Mansell-Carstens, 1996: 294-96). This view also stresses that the bankers evidently believed that they had purchased secure oligopolies. (Gruben and Welch 1996). They underestimated, however, the degree to which banking markets in Mexico were contested. Thus, the bankers found themselves in a scramble for market share. As Gruben and McComb (1997 and 2003) have shown, Mexico's banks competed so aggressively for market share that they operated beyond the point where marginal costs equaled marginal revenue.

The inexperienced banker view would also stress that Mexican bankers neither knew how difficult it would be to assess credit risks, nor understood how difficult it would be to enforce their property rights once borrowers reneged. Bankruptcy procedures in Mexico were (and still are) cumbersome in the extreme. Not only did the country have few bankruptcy judges, the bankruptcy law required judges to pass resolutions on each and every objection presented by debtors. Debtors could therefore delay the recovery of property by raising long strings of objections - and they could obtain information about how to file these objections from publications of the country's various debtor organizations. In addition, even when favorable judgments were rendered, they were not always enforced. As a consequence, the attempt to recover collateral through the legal system often took between three and seven 
years. (Mackey 1999: 101). As a consequence, collateral recovery rates were amazingly low: five percent in 1991 and 1992, seven percent in 1993, and nine percent in $1994 .{ }^{15}$

The second view, which we will call the tunneling view, would stress that Mexico's bankers were not sheep to be fleeced, they were experienced businessmen who understood the environment in which they operated. It would also stress the fact that some of the banks had been purchased with funds from those same banks, in which the collateral for the loans were the bank shares. (Mackey 1999: 141). Finally, it would stress the fact that evidence from later in the 1990s (the period 1995-98, when the government was intervening insolvent banks) indicates that the bankers had engaged in widespread insider lending, and that the loans they made to themselves had lower interest rates, higher rates of default, and lower rates of collateral recovery than unrelated arm's-length loans. (La Porta, Lopez-de-Silanes, and Zamarripa 2003.)

There is not yet sufficient evidence to adjudicate between these two views. The inexperienced banker view receives considerable support from the fact that in 1996 there were roughly 1.75 million debtors who participated in various government-run, debtor relief programs. (Mackey 1999: 92). The tunneling view receives considerable support from the La Porta et. al. research on the higher propensity of related loans to go in to default. La Porta et. al, however, focus on the period when the banks were already being intervened and/or bailed out by the government. Mexico's bankers may have realized that they were about to lose control of their banks, and thus had strong incentives to make loans to themselves that they

${ }^{15}$ The situation was actually much worse than these figures indicate, because Mexico's departure from generally accepted accounting practices lowered the reported levels of non-performing loans. See Table 3 for the sources from which we made these estimates. 
did not intend to repay. An analysis of loan portfolios during the period 1991-95 would help adjudicate between the two hypotheses.

\section{The Expansion of Credit and the Growth of Non-Performing Loans}

Regardless of the specific mechanism, one thing is certain: bank credit in Mexico grew at a prodigious rate. As Table 4 demonstrates, total real bank lending almost doubled in the space of just three years (1991-94). Housing loans grew at an even faster rate: from December 1991 to December 1994 real lending for housing and real estate nearly tripled. Moreover, this is a lower bound estimate of the growth of housing lending because it includes only performing loans. Much of the housing portfolio was non-performing, and the principal value and past due interest of those loans were continually rolled over into an accounting category called "rediscounts." (See Table 4). Inasmuch as the value of rediscounts was nearly equal to the total value of housing loans in December 1994, the threefold increase in housing loans from December 1991 to December 1994 is a lower bound estimate. The actual rate of growth might have been nearly twice that. ${ }^{16}$

Notably, the rapid growth in lending was not matched by an equally rapid growth in deposits. In 1993, 1994, and 1995 loans outstripped deposits by roughly 20 percent: the difference was funded through inter-bank lending, predominantly from foreign banks in foreign currency. (Mackey 1999: 60, 98). Foreign denominated liabilities therefore grew rapidly, from 11 percent of total Mexican bank liabilities in December 1991 to 14.7 percent in December 1993, to 27 percent in December 1994. As Mishkin (1996) has pointed out, the practice of Mexican banks of matching these foreign denominated liabilities with foreign

\footnotetext{
${ }^{16}$ The Comision Nacional Bancaria y de Valores, the regulator, did not ask banks to report nonperforming loans in a disaggregated fashion in the early 1990s, thus we do not know the composition of the nonperforming loan portfolio.
} 
denominated assets (loans made to Mexican firms in dollars) did not reduce the bank's exchange rate risk. Unless the borrowing firms had sources of income in dollars, they would have had great difficulty in servicing their debts in the event of devaluation. In point of fact, the borrowers tended not to have sources of income in dollars (Krueger and Tornell 1999).

Even more rapid than the growth in lending, was the growth of non-performing loans. Table 3 presents estimates of non-performing loans based on different ways of treating the various rollovers and restructurings that were permitted under Mexican accounting rules. One way that banks handled past due principal was to "rediscount" them—essentially creating a category of rollovers that reflected the low probability that the loans would be repaid. These rediscounts were not listed in the portfolio of performing loans, but they were not listed as being non-performing either. If we add these rediscounts to declared non-performing loans, then the default rate jumps dramatically. For example, instead of being 3.6 percent in December 1991, (the declared ratio of non-performing to total loans) the ratio would have 13.5 percent. Instead of being 6.1 percent in December 1994 (the declared rate) it would have been 17.1 percent. The practice of "rediscounting" loans began to be phased out by banks in 1995. Instead, they began to renew or restructure unpaid principal, and treated these rollovers as performing. Treating these rollovers as past due loans produces even more striking results. Instead of a non-performing ratio of 5.7 percent in December 1996, the ratio jumps to 32.5 percent.

Even this figure is likely an underestimate, because beginning in February 1995 banks were allowed to swap many of their loans for promissory notes from Mexico's deposit insurance system as part of a bailout (a subject to which we will return at length). If we add the value of these promissory notes to the value of declared non-performing loans, 
rediscounts, and restructured or renewed loans, then the percentage of loans that were nonperforming actually exceeded the percentage of loans that were in good standing: in December 1996 the non-performance ratio would have been 52.6 percent.

\section{Collapse and Bailout}

Even had there been no peso crisis of 1994-95, the Mexican banking system would have collapsed. The government's mishandling of the exchange rate merely hastened the banking system's demise. The crawling peg exchange rate policy of the Salinas government had been established to help fight inflation, and it had been largely successful in accomplishing that goal. Given the fact that Mexican interest rates were considerably higher than U.S. rates, and that the government was signaling an intention to maintain a stable exchange rate, there were strong incentives for both Mexicans and foreigners to deposit funds in Mexican banks. There were also incentives for Mexican firms, including banks, to sign debt contracts denominated in dollars. By the end of 1994, however, it was becoming increasingly clear that the exchange rate was overvalued. Once that happened, bank depositors had every incentive to withdraw their funds and convert them to dollars before the government allowed the currency to float freely. Firms with dollar denominated debts could not, however, act so quickly: as a result, the peso value of their debts nearly doubled in the space of a few days once the exchange rate was allowed to float.

The collapse of the exchange rate created two problems for the banking system. First, foreign currency loans represented roughly one-third of total loans made by Mexican banks. Many of these loans, however, had been made to firms without sources of foreign currency income. (Krueger and Tornell, 1999). Second, the collapse of the peso gave foreign portfolio investors strong incentives to pull their funds out of Mexico. Net foreign portfolio investment 
flows turned negative in the last quarter of 1994, and stayed there all through 1995. (Mishkin 1996:31). This required that the government pursue a tight monetary policy, raising central bank interest rates. The interbank loan rate, at its peak, hit 114 percent. Mortgage interest rates jumped to 74 percent by March 1995, from 22 percent just five months before. (Gruben and McComb 1997). The rapid rise in interest rates pushed risky, but performing, loans into default. As the stock of non-performing loans mounted, and as the size of the deposit base shrank because of the run on the peso, the banks became insolvent.

The dimensions of the collapse can be seen through several measures of bank performance. In Table 3 we estimate the ratio of non-performing to total loans. If we include principal rollovers and the value of FOBAPRA promissory notes as non-performing, then the ratio of non-performing loans grew from 17 percent at the end of 1994 to 36 percent by the end of 1995, and to 53 percent at the end of 1996. As debtors stopped making payments, income from loans dropped precipitously. Net interest margins (the spread between what banks charge for loans and what they pay depositors) actually became negative from December 1995 to September 1997 (Haber 2005).

\section{The Unlimited Liability of the Mexican Government}

The collapse of the credit system sent the economy into a tailspin. Precisely because it had created such a generous safety net in order to induce bankers, shareholders, and depositors into the game, it was now the government's responsibility to fix things: to rescue debtors ruined by the rise in interest rates and depositors whose savings had been lost through recklessness, and to restore the operation of the financial system, lest the economy go into complete free fall. 
The government therefore responded with a bailout of the banking system - the particulars of which warrant some discussion. First, Mexican banks had significant amounts of short term, dollar denominated debt. The government therefore opened a special dollar credit window at the Banco de México to provide them with foreign currency.

Second, the government sought to prop up the banks by lending them the capital necessary to maintain adequate reserves. A trust fund was created (known as PROCAPTE) by the government's bank deposit insurance agency (FOBAPROA) with funds provided by the central bank. This trust fund lent the banks capital sufficient to maintain a 9 percent capital ratio in exchange for five-year subordinated debentures from the bank. In the event of non-payment, the debentures were convertible to ordinary stock that could be sold by the government. ${ }^{17}$ Banks were enjoined, during the period that they participated in PROCAPTE, from issuing dividends or from issuing additional debt instruments to capitalize the bank. (Mackey 1999: 65).

Third, the government moved to protect borrowers, and in so doing protected the banks. There were several debtor protection programs, and as time went on the extent and terms of these programs became gradually more lenient. As a first step, the government created an indexed accounting unit (the UDIS) and allowed loans to be re-denominated in these units. Banks were then allowed to transfer loans to a government trust fund, which converted them to UDIS and which bore a real interest rate of four percent plus a margin to reflect the credit risk of the borrower. A series of additional programs soon followed, each of which was targeted at different groups of debtors (including consumers, the holders of home

\footnotetext{
${ }^{17}$ In the event of non-payment, however, the shares likely would not have had much value.
} 
mortgages, small businesses, and agriculture) and each of which was reformed over time to offer debtors even larger discounts off of their payments. (Mackey 1999: 82-86).

Fourth, the government cleaned the bank's balance sheets of non-performing loans through a loan repurchase program run by FOBAPROA. In exchange for their nonperforming assets, the banks received a non-tradable, zero coupon ten-year FOBAPROA promissory note that carried an interest rate slightly below the government CETES (Treasury bond) rate. The bankers agreed that for each peso in FOBAPROA bonds they received, they would inject 50 centavos of new capital, so as to recapitalize the bank. Banks were charged with collecting the principal and interest on the loans transferred to FOBAPROA. As a practical matter, however, they did not do so. (Krueger and Tornell, 1999; Murillo 2005). Banks that were in serious financial distress were intervened by the government's National Banking and Securities Commission (known by its Spanish acronym, CNBV). When a bank was intervened, the CNBV seized control of the bank and suspended shareholder rights. It then replaced the management of the banks and appointed a managing intervener. The CNBV intervener cleaned the non-performing loans from the balance sheet through the FOBAPROA bond mechanism discussed above and injected new capital through the PROCAPTE program. The government, via FOBAPROA, also guaranteed all of the deposits of the bank. Finally, the CNBV arranged for the bank to be sold to another institution, or it liquidated the bank. In some cases, the CNBV carried out a de facto intervention: in which it removed the bank's management and then arranged for another financial institution to invest in or acquire control of the bank. In all, 12 banks were formally intervened, with another three undergoing de facto intervention. That is, 15 of Mexico's 18 banks were intervened by the government. 


\section{Moral Hazard}

The government's intervention and bailout appears to have given some bankers the incentive to make large loans to themselves - and then default on the loans. ${ }^{18}$ As La Porta et. al. (2003) have shown, 20 percent of all large loans from 1995 to 1998 went to bank directors. These insider loans carried lower rates of interest than arm's length loans (by four percentage points), had a 33 percent higher probability of default, and had a 30 percent lower collateral recovery rate.

The looting of the banks by their own directors was, in fact, made possible by a revision of the rules governing the FOBAPROA loan repurchase program. When the program was first instituted in 1995, the following types of loans were ineligible for repurchase by FOBAPROA: past due loans; loans held by companies in bankruptcy; loans discounted with development banks; loans denominated in UDIS, and loans to related parties (loans to directors, their families, or their firms). As the situation of the banking system continued to deteriorate, however, the Technical Committee of FOBAPROA dropped these restrictions. (Mackey 1999: 70).

Moreover, there were no general guidelines regarding limitations and restrictions on the whole range of FOBAPROA programs. Not surprisingly, the FOBAPROA bailout was not (as originally anticipated in early 1995) a one-time event. Rather, it became an open-ended

${ }^{18}$ Mexico's bankers had been engaged in related lending for over 100 years before the failed related loans of 1995-98. Related lending during this earlier period was a rational response to the difficulty of enforcing contract rights through the legal system and did not result in the bankers looting their own banks. First, bank directors monitored one another through complex networks of interlocking directorates. Second, shareholders developed mechanisms to monitor directors. Third, because there was no deposit insurance, depositors policed banks by withdrawing deposits from risky banks. (Maurer 2002; Del Angel Mobarak Mobarak, 2002; Maurer and Haber 2007). 
mechanism, with loans being transferred from the banks to FOBAPROA through 1999. Thus, the percentage of bank loan portfolios composed of FOBAPROA bonds grew from 9 percent in 1995, to 20 percent in 1996, 29 percent in 1997 and 1998, and finally topped out at 35 percent in 1999. (See Table 3). For the same reason, bank interventions were also not a onetime event, but were spread out from 1994 to 2001. As of June 1999, the total cost of the bailout programs was 692 billion pesos ( $\$ 65$ billion) roughly 15 percent of Mexican GNP. (Murillo, 2005).

The fact that the banking system bailout involved an implicit transfer from taxpayers to bank stockholders, who included some of Mexico's wealthiest men, produced a political firestorm in Mexico. It fueled the expansion of a national debtors' protest movement (the most prominent manifestation of which was an organization known as "El Barzón," named for the yoke ring to which an ox-drawn plow is attached), and, in the run-up to the 1997 midterm congressional elections, it contributed to the expansion of opposition political parties, which capitalized on the fact that millions of small businesses and middle-class debtors were pushed into bankruptcy as a result of sharply increased interest rates and the collapse of the banking system. Newly empowered congressional representatives from opposition parties subsequently insisted on an investigation into the mechanisms that had been used to rescue commercial banks before they would approve any further bailouts, a maneuver that held up approval of the 1999 federal budget for a full 9 months. Ultimately, Congress agreed to disband FOBAPROA and replace it with a new (more autonomous) deposit guarantee agency, the Bank Savings Protection Institute (known by its Mexican acronym, IPAB). Most (although not all) FOBAPROA bonds were swapped for IPAB bonds, and IPAB was given the task of recouping and liquidating the assets backed by those bonds. 
This was a de facto admission that the loans that had been swapped for FOBAPROA promissory notes were unrecoverable. Congress also agreed that the annual cost of the banking sector rescue would be paid for by the government out of each year's budget. (McQuerry 1999). This was a de facto admission that the new IPAB bonds had the status of sovereign debt.

\section{How Unusual is Mexico's History of Banking Instability?}

Readers may be wondering whether Mexico's history of a banking crisis induced by a government expropriation followed by a banking crisis induced by a mismanaged privatization is unusual, when viewed from the perspective of the experiences of other countries. Let us leave aside the particulars about expropriations and failed privatizations, and set the bar lower by simply asking how many countries around the world had back-toback banking crises, one in the 1980s, and another in the 1990s.

In order to do so, we draw upon the database on banking crises and their resolution, constructed by Laeven and Valencia (2010). We integrate this database with the World Bank’s Financial Structure Database (November 2010 update), in order to be able to compare crisis and non-crisis countries. We exclude countries that are or were communist (because it is not clear what it means to have a banking system when there are no prices or interest rates), as well as countries that are not sovereign, or that do not provide any information about their banking systems to the World Bank. This leaves us with 144 countries.

Only 14 of those 144 countries, roughly ten percent, had back-to-back banking crises in the 1980s and 1990s. Moreover, the group of multiple crisis countries is far from a random draw; it includes some of the worst governed countries on the planet. The group includes Cameroon, Chad, the Democratic Republic of the Congo, Guinea, Kenya, the Philippines, 
Morocco, Bolivia, Argentina, Ecuador, Colombia, Costa Rica, and, of course, Mexico. In short, the answer to the question, is Mexico's pre-1997 experience unusual, is an unequivocal yes.

\section{The Search for New Partners}

Saving the Mexican banking system not only required a taxpayer-funded bailout, it required that the government of President Ernesto Zedillo find a way to put the banking system on sounder footings. That is, the government had to find a new set of bankers with which to partner. The question was, what rules would align the incentives of the partners?

The Zedillo government took a two-pronged approach. First, it revamped the regulatory and monitoring system. Second, it recruited new partners by letting foreign banks take over a large share of the Mexican market.

The Zedillo government undertook five reforms designed to improve monitoring and recapitalize commercial banks. First, it made insider lending more difficult to carry out. Banks were required to publish consolidated accounts that included the operations of their subsidiaries. Banks were also precluded from making loans to bank officers and employees that were not part of their employee benefits. Related party loans were allowed, but they could not exceed the net capital of the bank. ${ }^{19}$

Second, banks were required to diversify risk. As of June 1998, bank loans to any individual could not exceed ten percent of the bank's net capital, or 0.5 percent of the total net capital of all banks. The same law also enjoined banks from granting loans to companies that

${ }^{19}$ Prior to 1995 related party loans could not exceed 20 percent of the total portfolio of the institution. Related party loans often exceeded even this extremely permissive limit. (Mackey 1999: 141). 
exceeded 30 percent of the bank's net capital, or six percent of the total net capital of all banks.

Third, the government increased capital requirements and introduced a regulatory system that established reserve minimums in accordance with the risk of a bank's portfolio. In particular, banks were required to access the credit record of borrowers (by using a credit bureau). Loans in which the credit records were not checked (or in which they were checked, but they were poor) had to be provisioned at 100 percent. (Mackey 1999: 117).

Fourth, as of January 1, 1997 new accounting standards, which more closely approximate generally accepted accounting standards, went into effect. For example, the accounting treatment of past-due loans was reformed to bring it into line with generally accepted standards. In addition, repurchase agreements were no longer treated as assets, and inter-bank loans had to be separately grouped in financial statements. (Del Angel Mobarak, Haber, and Musacchio, 2006). Mexican banks still did not, however, adhere to all features of generally accepted accounting standards. In particular, banks were still allowed to record deferred taxes as Tier I capital. That may have overstated the quantity and quality of the capital available to the banks. (Mackey 1999: 127-29). ${ }^{20}$

Finally, the rules governing deposit insurance were reformed. Unlike its predecessor (FOBAPROA), IPAB does not provide unlimited insurance. As of January 1, 2005, insurance is limited to 400,000 UDIS (roughly $\$ 100,000$ at the current rate of exchange) and covers bank deposits only, instead of a broad range of bank liabilities.

${ }^{20}$ For a detailed discussion of bank accounting changes in Mexico see Del Angel Mobarak, Haber and Musacchio (2006). 
The second part of the process to redesign the Bank Partnership included the search for new partners. For that purpose, the Mexican government lifted the restrictions on foreign ownership of commercial banks. The government began to remove restrictions on foreign bank acquisitions of Mexican banks in February 1995, when foreign banks were permitted to purchase Mexican banks with market shares of six percent or less. This still kept the largest Mexican banks off the table. In 1996, all restrictions were removed on foreign bank ownership in Mexico (with the new regulations going into effect in 1997). As a result, foreign banks began to purchase controlling interests in Mexico's largest banks. In December 1996, just prior to the new rules regarding foreign ownership, foreign banks controlled only seven percent of total bank assets in Mexico. Roughly one-half of these foreign-controlled assets were in freestanding small banking operations that did actually do much in the way of retail banking. By December 1999, 20 percent of bank assets were controlled by foreign banks, and as of December 2003 the share of Mexican bank assets under foreign control increased to 82 percent. (See Table 1 and Figure 1).

The stabilization of the Mexican banking system via foreign entry can be seen in Tables 5 and 6, which present data on the ratio of (non-risk weighted) capital to assets and the ratio of non-performing loans to total loans. As Table 5 shows, the equity ratio increased steadily, from 9 percent at the end of 1997 to 13 percent by the end of 2006 . The biggest increases came in the Foreign MA banks, where the equity ratio jumped from only four percent in 1997 to 14 percent by 2007. The implication is straightforward: when Mexican banks were initially purchased by foreign banks they were seriously under-capitalized, and their purchase by foreign banks succeeded in recapitalizing them. At the same time, the ratio of non-performing to total loans fell dramatically, from 11 percent in 1997 to two percent by 
2005. (See Table 6). The biggest decline came in domestic banks, where the ratio was 12 percent in 1997, and 1 percent in 2004. Driving this decline was the purchase of domestic banks by foreign banks (after purchase, banks that were previously coded as domestic are now coded as Foreign MA in Table 6, hence their NPL ratios move inversely to one another from 1997 to 2002). That is to say, the data suggest that foreign banks purchased the domestic banks with the weakest loan portfolios, and then cleaned up those portfolios - a finding that we confirm in the next section through econometric analysis. ${ }^{21}$

The evidence also indicates that the entry of foreign banks was coterminous with the return of the Mexican banking system to profitability. As Table 7 shows, returns on both equity and assets have climbed steadily since 1997, so much so that the 2008-09 banking crisis that affected the developed world—most especially Mexico's northern neighbor—does not appear to have had a major effect on the stability of the banking system. Rates of return on assets and equity fell from 2007 to 2008, but Mexico's banks, regardless of their ownership status, continued to post positive returns on equity.

${ }^{21}$ One might normally be concerned about the fall-back in equity ratios that appears to have occurred after 2006 (See Table 5). The data on non-performing loans (Table 6), however, indicate that by 2006 banks no longer had to provision heavily against loan-losses. 


\section{Section Five}

\section{Did Foreign Bank Entry Improve Social Welfare in Mexico?}

Now that we understand the facts related to the government's decision to allow foreign banks to purchase Mexico's largest banks, as well as open the market to foreign entry more broadly, we are in a position to draw on the financial economics literature in order to design an econometric strategy to estimate the effect of foreign entry on the behavior and performance of Mexico's banking system.

Making a causal statement about the impact of foreign entry on the volume, price, or volatility of credit requires the researcher to first ask, "raise (or lower) the volume, pricing, and volatility of credit, as compared to what?" Simply stated, we cannot compare the Mexican banking industry in 2012 to the Mexican banking industry that would have existed in 2012 in the absence of liberalization, because that hypothetical Mexican banking industry does not exist.

We also cannot compare the Mexican banking industry in 2012 against the banking industry of another country (or group of countries) that was just like Mexico prior to 1997, but that then did not liberalize the rules governing the entry of foreign banks. As the previous section makes clear, Mexico's expropriation of the banks in 1982, the failed bank privatization of 1991-92, and the banking crisis of 1995-95, were singular events. An appropriate counterfactual case would not just need to have had Mexico's level and distribution of income, as well as a pre-1997 banking system that closely mirrored that of Mexico in terms of its structure and institutions, it would also need to have experienced a banking crisis similar to that of Mexico in the mid-1990s, but then did not respond to that 
crisis by opening up to foreign entry. The popular aphorism, "Como México, no hay dos" actually has deep analytic meaning.

Making matters more complicated still, the laws governing foreign entry were only one of a series of changes that occurred in Mexico after 1997. Some of those changes affected the banking industry narrowly. For example, between 1997 and 2001, the government changed the accounting rules and standards for bank financial statements, made it more difficult for banks to make related-party loans, increased the statutory limits on deposit insurance, increased requirements governing provisions for loan losses, and changed the legal basis of mortgage contracts in order to make them easier to enforce. Other changes were much broader in character, not the least of which was that Mexico democratized, and as a result the government became much more active in supporting private lending in the housing market through the Sociedad Hipotecaria Federal. In and of themselves, without foreign entry, these changes would have affected the behavior and performance of Mexico's banks. Hence, we cannot simply compare Mexico's pre-1997 banking system to its post-1997 banking system and infer that any observed differences were caused by foreign entry. Doing so would imply the specification of a hypothetical Mexico in which there had not been a disastrous bank privatization, a taxpayer-financed rescue, and a subsequent demand by citizens that the rules governing the banking system, as well as the rules governing the political system, be reformed.

Making matters even more complicated, the liberalization of Mexico's banking laws did not just lead to a one-time of wave of foreign entry or an immediate change in bank behavior. The effects of foreign entry were felt gradually and affected Mexican banks asymmetrically. Banks changed their behavior when they were acquired by foreign banks, 
but they were not acquired at the same time. Moreover, non-acquired banks, those that remained domestically owned, subsequently faced a different competitive environment, and had to respond by changing their own behavior. These changes included mergers with other domestically-owned banks. In short, any reasonable identification strategy has to be able to capture changes within the banking system as a whole, as well as changes within types of banks within that system.

Finally, we need to take account of the fact that the decision to open up Mexico's banking industry to foreign competition, as well as the decisions made by foreign banks to purchase specific Mexican banks, were not made randomly. The Mexican government changed the rules governing foreign entry in order to recapitalize an insolvent banking industry, one that had to be rescued from a disastrous privatization program. It might have been the case, therefore, that the Mexican government permitted foreign banks to purchase the Mexican banks that were the most distressed. Though researchers often draw simple comparisons between the behavior and performance of foreign-owned and Mexican-owned banks, doing so comes at the risk of drawing spurious inferences. Simply put, it is not reasonable to assume that had Mexico's largest banks remained in the hands of domestic owners, they would have behaved the same way-in terms of the volume of credit they offered, the price at which they offered it, and the distribution of that credit across different loan types - as the smaller banks that remained in the hands of domestic owners. They may well have been sold to foreign owners because that was the only way that the government could be sure that the banks would be properly recapitalized.

Providing a meaningful answer to the question of whether foreign bank entry raised or lowered welfare in Mexico therefore requires us to exploit two sources of variance. The first 
is variance within the banks that were purchased by foreign banks, controlling for changes that occurred among all banks. That is, we compare banks against themselves before and after they were bought. We do so by building a unique bank-level dataset covering the 54 quarters between mid-1997 and the end of 2011. We then control for unobservables, and the non-random distribution of bank types, by using bank fixed effects. Because Mexico's banks were bought at different times, and because we can control for the changes that affected all banks, we are able to draw inferences about the independent impact of being purchased by a foreign bank. The second is variance between foreign banks of various types, controlling for changes that occurred among all banks. That is, we compare the banks that were purchased by foreign banks to foreign banks that were set up as greenfield operations.

\section{Data}

In order to examine the effects of foreign bank entry into Mexico we use a database of bank financials that includes balance sheets, income statements, and loan portfolios on a quarterly basis for every retail bank in Mexico from September 1997 to December 2011, obtained either from the website of Mexico's Comisión Nacional Bancaria y de Valores (CNBV) or directly from the printed quarterly bulletins of CNBV (Boletín Estadístico de Banca Múltiple). ${ }^{22}$

The key to our identification strategy is to identify those banks that had been subject to mergers and acquisitions (both by other domestic banks and by foreign banks). We do this by

${ }^{22}$ WWW.CNBV.gob.mx. Readers who may wish to replicate or extend our results should be cautioned not to rely on the website alone, because the CNBV deletes historical data for banks that later merged with other banks or otherwise exited the market. Simply downloading the data from the CNBV website will produce a truncated sample of surviving, merged banks. We also had to fix the 1997 data, as well as the 2007-2011, which was reported in cumulative form - each quarter adding the previous quarters. 
tracking the bank charters and charter reforms as compiled by Mexico's Comisión Nacional para la Protección y Defensa de los Usuarios de Servicios Financieros (CONDUSEF), from 2003 to 2010. With this we end up having a dataset that allows us to follow banks over time, regardless of changes in name or ownership. ${ }^{23}$ Then, for each quarter, we code banks as Domestic, Foreign MA (for Mexican banks that were the product of a foreign acquisition), or Foreign de Novo, if they are a foreign greenfield bank or a foreign bank that acquired a foreign bank that was already operating in Mexico. ${ }^{24}$ Table 8 identifies the banks in our database and shows how they were coded.

As we mentioned before, the liberalization in the banking system in 1997 did not cause a switch of ownership of Mexican banks right away. Thus, our study is not a before and after 1997 study. In fact, we purposely do not include observations before September 1997 because in order to prevent a reoccurrence of the 1995-96 banking crisis, the government reformed bank accounting standards in 1997 . This means that it is not possible to link data from before September 1997 with data from after September 1997 (Del Angel Mobarak, Haber, and Musacchio 2006).

Nevertheless, our data set captures the period in which the greatest changes in Mexican bank ownership occurred. At the beginning of the period under study (September

${ }^{23}$ The URL for this site has changed over time. Its current location is: http://sipres.condusef.gob.mx/home/SQLsectoresSHCP.asp?ID=40.

${ }^{24}$ Foreign MA was coded as 1 if a foreign bank purchased a controlling interest in a domestic Mexican bank. This means that the Mexican bank continues to exist as a reporting unit, although its name is sometimes altered to reflect the change in ownership. For example, when the Banco de Bilbao y Vizcaya purchased a controlling interest in Bancomer, the merged bank was renamed BBV Bancomer. Some foreign banks even bought two Mexican banks. For instance, Santander is coded as Foreign MA from the beginning of the database because it purchased Banco Mexicano. When Santander purchases Serfin, however, we code Serfin and its subsequent observations as Foreign MA. In short, the idea of our Foreign MA code is to track Mexican banks right after they switch to being foreign. 
1997), the vast majority of the foreign banks in Mexico were extremely small operations. In point of fact, in September, 1997 there was only one Foreign MA bank operating in Mexico (the Banco de Santander, which had acquired a small Mexican bank in 1993), with a 7.7 percent market share. Fifteen foreign de novo banks accounted for an additional 8.3 percent of the loan market. By late 2007 there were six Foreign MA banks operating in Mexico (Banamex, BBVA Bancomer, Santander Serfin, GE Capital Bank, Bital, and Scotiabank Inverlat) with a combined loan market share of 74.2 percent. This share then declined to $65 \%$ by the end of 2011. Between 2004 and 2011, Foreign de Novo banks accounted for an additional 1.8 percent of the loan market. In short, the total foreign market share, as measured by loan volume, mushroomed from 16 percent in September 1997 to 67 percent by December 2011.

\section{Methods}

We study the impact of foreign entry on a series of variables. In order to do so, we follow the approach of Martínez Peria and Mody (2004), who study interest rate spreads in foreign banks in Latin America. ${ }^{25}$ We mimic their baseline model, but add bank fixed effects and then add controls for the characteristics of loan portfolios. Their approach was strictly to compare foreign and domestic bank net interest margins in a cross-section, while our identification strategy is to compare Mexican banks before and after they turned foreign, controlling for the behavior of all other banks as well as for common shocks that affect all banks. Thus, we employ the following specification with and without bank fixed effects:

${ }^{25}$ Their framework draws on two bodies of literature: the dealership model of bank spreads developed by Ho and Saunders (1981), Allen (1988), Angbazo (1997), and Brock and Rojas Suarez (2000); and the firm-theoretic model of bank spreads developed by Zarruck (1989) and Wong (1997) 


$$
N_{i, t}=\alpha_{0+} \alpha_{1} \text { iquidity }_{i t}+\alpha_{2} \text { Admin }_{\text {Costs }}^{i, t}+\alpha_{3} N P L_{i t}+\alpha_{4} \text { Equity }_{i t}+\alpha_{5} \text { Bank }
$$

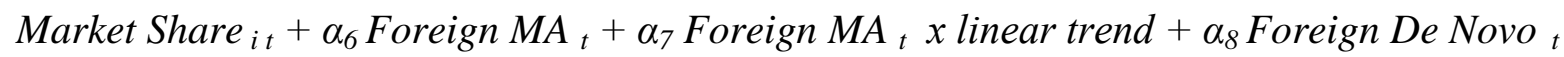

$+\alpha_{9}$ Foreign De Novo $_{t} x$ linear trend $+\alpha_{10}$ Housing Loans $_{i t}+\alpha_{11}$ Commercial Loans $_{i t}+$

$\alpha_{12}$ Consumer Loans $_{i t}+\alpha_{13}$ Fobaproa-IPAB $_{i t}+\alpha_{14}$ Bank $_{i,}+\alpha_{15}$ Quarter dummy $_{t,}+e_{i t}$ (1)

where $i$ is the bank id and $t$ refers to the time period considered. NIM, the net interest margin, or loan spread, is calculated as interest on loans over total loans minus interest paid to depositors over total deposits. Equity is the ratio of a bank's equity to its assets. In theory, higher equity ratios should discourage risky lending, because more stockholder wealth is at risk. Liquidity is the ratio of cash (including deposits in other banks or in the central bank) to assets, Admin Costs is the ratio of administrative costs to total assets, and NPL is the ratio of non-performing loans to total loans. Bank Market Share is the proportion of each bank's loans to total system loans. We employ robust standard errors.

Our variables of interest are Foreign $M A$, which is a dummy variable that takes a value of 1 at each point in time that a bank is owned by a foreign bank and Foreign De Novo, which is a variable that takes a value of 1 at each point in time that a bank is a foreign-owned greenfield operation. ${ }^{26}$ These allow us to compare Foreign MA and De Novo banks to domestic banks. Including them separately permits us to draw inferences about behavior that is linked to foreignness per se: if the coefficients for these variables have the same sign and significance, it implies that foreign owners take a different approach to the Mexican market than domestic banks; if the coefficients are of different sign and significance, it implies that

${ }^{26} \mathrm{We}$ do not add additional controls for mergers and acquisitions among domestic banks because there is not enough variation to make it worthwhile. 
the differences between these bank types and domestic banks is driven by some unobserved characteristic other than their foreignness. We also interact each of these variables with a time trend to see if the behavior of foreign banks changes over time.

Our models also control for the characteristics of bank loan portfolios by including the percentage of housing, commercial, and consumer loans to assets. Additionally, we control for the fact banks held FOBAPROA-IPAB bonds, by including the ratio of those bonds to total assets in each bank (FOBAPROA-IPAB). We also included controls for bank nationality in some specification to see if Foreign MA banks behave differently from Foreign De Novo banks due to nationality, rather than for simply being foreign. We do not include them here because nationality of the banks that acquired Mexican banks is not driving our results.

The Mexican banks that were acquired by foreign banks tended to be large, undercapitalized, and distressed — which is precisely why the Mexican government allowed them to be purchased by foreigners in the first place — and these characteristics may be correlated with performance outcomes. Our specifications control for this potential problem by including variables for the equity ratio, liquidity ratio, composition of the loan portfolio, and the ratio of a assets composed of bailout bonds (FOBAPROA and IPAB) to all other assets. In order to control for serial correlation we cluster the (robust) standard errors by bank.

Table 9, which presents summary statistics, suggests that there may be differences in the behavior and performance of Foreign MA banks and domestic banks. Foreign MA banks appear to charge lower net interest margins, earn higher rates of return on assets and equity, and participate more aggressively in the market for mortgage loans, while being less involved in the commercial lending market. Foreign de Novo banks do not appear to mirror the 
behavior or performance of Foreign MA banks, but neither do they mirror the behavior and performance of domestically-owned banks. The data suggest, in short, that these three types of banks may operate in different segments of the credit market. 


\section{Section Six}

\section{Econometric Results}

We divide our econometric tests into three broad categories. First we look at the effects of foreign bank entry on the pricing of loans using our net interest margin (NIM) regressions. Second, we look at the effects of foreign bank entry on the stability of the system by looking at the riskiness of bank loan portfolios (as measured by the proportion of nonperforming loans to total loans). Finally, we study the effects of foreign bank entry on the volume of credit made available to the private sector.

\section{Effects of Foreign Bank Entry on the Pricing of Credit}

Has the entry of foreign banks in Mexico caused net interest margins to increase or decrease? Table 10 presents the results of the regressions on net interest margins that we specified in Section IV. Specification 1 is estimated with random effects and includes quarter dummies, and is therefore primarily picking up differences in means between different bank types. It suggests that, once the composition and risk of loan portfolios, administrative costs, equity ratios, liquidity ratios, and common shocks affecting all banks are controlled for, there is no difference between the net interest margins charged by Foreign MA banks and the net interest margins charged by domestic banks. Foreign de Novo banks charge net interest margins that almost 2 percentage points lower than domestic banks. Given that the sample mean is only 0.029 , these results are not just statistically significant they are economically significant. The regression also suggests that there is no difference between Foreign MA banks, Foreign de Novo banks, and domestically owned banks in the movement of net interest margins over time (the time trend, as well as the interaction of the time trend with Foreign MA and Foreign de Novo, are either perfectly estimated at zero or are not statistically 
significant). This suggests that domestic banks are not closing the gap between what they charge and what foreign banks charge.

Because the time trend and its interactions with bank ownership types did not pick anything up, and they may be coming at a cost to the model, we re-estimate the regression in Specification 2 dropping the trends and interactions. The coefficient on the Foreign de Novo

dummy continues to be statistically and economically significant. The coefficient on Foreign MA is negative (they charge lower net interest margins than domestically owned banks), but it is not statistically significant at conventional levels.

Specification 3 of Table 10 is estimated using bank fixed effects. The coefficient on Foreign MA is now picking up the impact on interest margins of a domestic bank being acquired by a foreign bank. It suggests that, once the composition and risk of loan portfolios, administrative costs, equity ratios, liquidity ratios, common shocks affecting all banks, and the behavior of other banks are controlled for, being purchased by a foreign bank has no effect on net interest margins. In short, there is no evidence that foreign entry has reduced welfare by increasing the price of credit, while there is some evidence that it has increased welfare.

\section{Effects of Foreign Bank Entry on System Stability}

Wong (1997) develops a theoretical model about net interest margins that suggests that when a bank charges lower margins it does so either because its loan portfolio is less risky or because it is risk-loving. The detailed nature of our data allows us to evaluate directly the hypothesis that there are differences in the risk of loan portfolios across foreign and domestic banks in Mexico. We can simply employ the regression framework above, but substitute the ratio of non-performing loans for net interest margins. 
Table 11 presents the results, and they suggest that foreign banks have less risky loan portfolios. Specification 1 of Table 11 estimates the NPL regression using random effects and quarterly dummies, and thus primarily picks up differences between bank types. It indicates that, controlling for the distribution of the loan portfolio, equity ratios, liquidity ratios, administrative costs, and common shocks affecting all banks, loans made by Foreign MA banks are neither less nor more likely to become non-performing than loans made by domestically-owned banks. It also suggests that loans made by Foreign de Novo banks are much less likely to become non-performing: the coefficient of -0.071 indicates that, on average, their ratio of non-performing loans is 7 percentage points below that of domestic banks. Given that the same mean is only 0.034 , this is an economically large effect. Specification 2 of Table 11 includes bank fixed effects, and thus the Foreign MA variable now picks up the effect of a bank switching from domestic to foreign ownership (controlling for the distribution of the loan portfolio, equity ratios, liquidity ratios, administrative costs, common shocks affecting all banks, and the behavior of other banks). The coefficient of -0.065 suggests that after a domestically-owned bank was acquired by a foreign bank, its ratio of non-performing loans fell by 6.5 percentage points. This result is not just statistically significant (at the one percent level) it is economically of very large magnitude. In short, the regressions point to a rather sizable decrease in the riskiness of a domestic bank's loan portfolio after it was acquired by a foreign bank.

These regression results are consistent with interviews we conducted with Mexican bankers and industrialists. In their accounts, after acquiring a domestic bank, foreign banks tended to centralize credit approval and upgrade the credit scoring system. Previously, Mexican banks such as Banamex, Bancomer and Serfin relied on regional credit committees 
that included local industrialists with long relationships with the banks. Those industrialists provided soft information to the credit committees and regional managers of banks. After being acquired by a foreign owner, however, those regional credit committees lost importance or disappeared.

Taken together, Tables 10 and 11 suggest that the domestic banks that were later acquired by foreign banks made loans that had a high probability of default, but they did not charge net interest margins commensurate with that degree of risk. Our results are therefore broadly consistent with those of La Porta, López-de-Silanes, and Zamarripa (2003), who find that between 1995 and 1998, Mexico’s bankers tended to make loans to their own enterprises at low rates of interest and inadequate collateral, and then defaulted on those loans. Our results may explain why, after they were intervened, the Mexican government did not sell them back to domestic owners.

\section{Effects of Foreign Bank Entry on Credit Provision}

Finally, we look at the effect on foreign entry into the volume of credit going to the private sector, where private sector lending is defined as the sum of credit for housing, consumer, and commercial purposes as a percentage of total bank assets. Our regressions include the usual controls from Tables 10 and 11, but also add controls for the net interest margins because we assume that the volume of lending is not independent of the interest rates charged on loans. The results, presented in specification 1 of Table 12, indicate that once we control for changes in bank fundamentals, as well as common shocks affecting all banks, Foreign MA banks and Foreign de Novo banks neither lend more nor less than domestic banks. 
Because the time trend and its interactions with bank ownership types did not pick anything up, and they may be coming at a cost to the model, we re-estimate the regression in Specification 2 dropping the trends and interactions. The coefficient on the Foreign de Novo dummy continues to be statistically insignificant. The coefficient on Foreign MA, however, is negative, but is not statistically significant at conventional levels. Nevertheless, it suggests (weakly) that Foreign MA banks may allocate less credit than domestic banks.

Specification 3 adds bank fixed effects, and thus the Foreign MA variable now captures the effect of switching ownership from domestic to foreign. It produces a negative coefficient, but it is not statistically significant at conventional levels. It suggests (weakly) that when a bank switches from domestic to foreign ownership (controlling for changes in bank fundamentals, common shocks affecting all banks, and the behavior of other types of banks), it may allocate less credit to the private sector.

This is not to say that credit growth has been decreasing in Mexico. Indeed, it has been increasing: as Table 4 shows, lending to the private sector roughly doubled in real terms between 1999 and 2011. It is to say, however, that the banks that switched ownership from domestic to foreign have not increased lending (as a percentage of assets) either compared compared to domestic banks or compared to themselves before they were sold. 


\section{Section Seven}

\section{Conclusions}

By the standards of other upper-middle income countries, Mexico has an extraordinarily small banking system. As Figure 3 shows, in 2009 commercial bank credit to firms and households in Mexico only amounted to 22 percent of GDP. This was more than one standard deviation below the mean for other countries in this income category, putting Mexico near the bottom of the distribution, along with countries such as Botswana, Algeria, the Dominican Republic, Peru, and Argentina. It is also the case that, by any standard, an extraordinarily large proportion of the Mexican banking system is foreign owned.

It is usually not a good idea to confuse correlation with causality, and the Mexican banking system is not an exception to this general rule. With the exception of the brief period 1991-94, when Mexico's banks were lending wildly because they had little capital at stake, Mexico has historically had a small commercial banking system. The reasons for the modest scale of commercial banking in Mexico, as we have shown in this paper, was the nature of the partnership between the Mexican government and Mexico's bankers. The tenuous nature of this partnership not only gave rise to rather modest levels of credit from commercial banks, it also gave rise to an unstable banking system. Indeed, whatever modest growth occurred from the 1920s to the 1960s was squelched by financial repression during the latter half of the 1970s, when the government chose to finance its deficits via an inflation tax and high deposit reserve rates. The government then expropriated the banking system outright in 1982 . When the government attempted to form a new partnership with a group of bankers, during the privatization of 1991-92, the nature of the deal that they crafted virtually guaranteed that the 
banking system would collapse in short order. In short, to the degree that one can point to a "good old days" of Mexican banking, we appear to be in it.

The post-1997 Mexican banking system has several characteristics that differentiate it from the banking system that existed in Mexico for most of the $20^{\text {th }}$ century. The system is extremely stable, in part, because there is less moral hazard built into the partnership between the government and the bankers. Mexico's foreign bankers have strong incentives not to mismanage their end of the partnership. The capital that they risk is real, not fictitious. They also have weak incentives to tunnel into their own banks, because they do not own downstream, non-financial companies. In addition, they are subject to much greater oversight, because at the same time that the government opened the market, it reformed accounting standards. They can also not expect to be bailed out by Mexican taxpayers. Should they behave imprudently, it is unlikely that they will receive the kind of open-ended guarantees that their Mexican counterparts received circa 1995-96. Finally, they are not just accountable to Mexican regulators, but are also accountable to dispersed shareholders abroad, as well as regulators in their home countries. In short, they have a lot of lose, and little to gain, from being opportunistic partners.

The partnership between the Mexican government and foreign bankers also gains strength from the fact that the Mexican government cannot easily expropriate foreign banks or otherwise reduce their property rights. Foreign bankers in Mexico, especially those from the United States and Canada, can access protection against the Mexican government from their home governments, as well as from international tribunals under NAFTA. In short, foreign bankers have protections against the Mexican government that Mexican bankers do not have. 
Finally, the Mexican banking system has become increasingly stable and efficient for another reason, one that is independent of the nationalities of the bankers: the Mexican government no longer has unlimited authority and discretion, because the parties in control of the government now operate under the rules of democracy. It would be a gross exaggeration to say that the rule of law is as strong in Mexico as it is in Sweden, but it would equally misguided to state that democratization since 1997 has not strengthened the rule of law. Mexico's bankers, regardless of their national origin, can no longer be expropriated with the stroke of a pen. Moreover, Mexico's taxpayers made it clear in 1997 that they will can and will punish governments that forge partnerships that are likely to fail, and leave them to bear the cost of the bank rescue. Mexico's "Game of Bank Bargains" has fundamentally changed. 


\section{References}

Acemoglu, Daron, Simon Johnson, and James Robinson. 2001. "The Colonial Origins of Comparative Development: An Empirical Investigation." American Economic Review 91: 1369-1401.

Acemoglu, Daron, Simon Johnson, and James A. Robinson. 2005. "Institutions as the Fundamental Cause of Long-Run Growth." In Handbook of Economic Growth. Vol. $1 A$, ed. Philippe Aghion and Steven Durlauf. The Netherlands: Elsevier Science.

Allen, Linda. 1988. "The Determinants of Bank Interest Margins: A Note.” Journal of Financial and Quantitative Analysis 3: 231-235.

Angbazo, Lazarus, 1997. "Commercial Bank Net Interest Margins, Default Risk, Interest-rate Risk and Off-Balance Sheet Banking.” Journal of Banking and Finance 21: 55-87.

Barajas, Adolfo, Roberto Steiner and Natalia Salazar. 2000. "The Impact of Liberalization and Foreign Investment in Colombia's Financial Sector." Journal of Development Economics 63: 157-196.

Barth, James, Gerard Caprio Jr., and Ross Levine, 2006. Rethinking Bank Regulation: Till Angels Govern. New York: Cambridge University Press.

Bazdresch, Carlos, and Santiago Levy. 1991. "Populism and Economic Policy in Mexico, 1970-82." In Rudiger Dornbusch and Sebastian Edwards, eds., The Macroeconomics of Populism in Latin America. Chicago, IL: University of Chicago Press.

Beck, Thorsten and Maria Soledad Martinez Peria. 2010. "Foreign Bank Participation and Outreach: Evidence from Mexico.” Journal of Financial Intermediation 19: 52-73.

Berger, Allen N., Leora Klapper, and Gregory F. Udell. 2001. "The Ability of Banks to Lend to Informationally Opaque Small Businesses." Journal of Banking and Finance 25: 2127-67.

Brock, Philip L. \& Rojas Suarez, Liliana. 2000. "Understanding the behavior of bank spreads in Latin America." Journal of Development Economics 63: 113-34.

Calomiris, Charles W., and Stephen Haber. Forthcoming. Fragile By Design: Bank Crises, Scarce Credit, and Political Bargains. Princeton: Princeton University Press.

Cárdenas, Enrique. 1996. La política económica en México, 1950-1994. Mexico City: El Colegio de México.

Cárdenas, Enrique. 2000. "The Process of Accelerated Industrialization in Mexico, 19291982.” In Enrique Cárdenas, José Antonio Ocampo, and Rosemary Thorp, eds., 
Industrialization and the State in Latin America: The Postwar Years, vol. 3 of An Economic History of Twentieth-Century Latin America. London: Palgrave.

Cardim de Carvalho, Fernando J. 2002. "The Recent Expansion of Foreign Banks in Brazil: First Results." Latin American Business Review 34: 93-119.

Cerutti, Mario, and Carlos Marichal eds. 2003. La banca regional en Mexico, 1870-1930. Mexico: Fondo de Cultura Económica.

Claessens, Stijn, Asli Demirguç-Kunt and Harry Huizinga. 2001. "How Does Foreign Entry Affect Domestic Banking Markets?” Journal of Banking and Finance 25: 891-911.

Clark, George, Robert Cull, Maria Soledad Martinez, Peria, and Susana M. Sanchez. 2003. "Foreign Bank Entry: Experience, Implications for Developing Economies, and Agenda for Further Research.” World Bank Research Observer 18 (1): 25-59.

Clark, George, Robert Cull, Maria Soledad Martinez, Peria, and Susana M. Sanchez. 2004. "Bank Lending to Small Businesses in Latin America: Does Bank Origin Matter." Unpublished paper.

Clarke, George, Robert Cull, and Soledad Martínez Pería. 2006. "Foreign Bank Participation and Access to Credit across Firms in Developing Countries." Journal of Comparative Economics 34: 774-95.

Clarke, George, Robert Cull, Laura D’Amato, Andrea Molinari. 2000. “The Effect of Foreign Entry on Argentina's Domestic Banking Sector." In Stijn Claessens and Marion Jansen, eds., Internationalization of Financial Services: Issues and Lessons for Developing Countries. London: Kluwer Law.

Comisión Nacional Bancaria y de Valores, Boletín Estadístico de Banca Múltiple, various issues.

Condon, Bradly, and Tapen Sinha. 2003. Drawing Lines in Sand and Snow: Border Security and North American Economic Integration. Armonk, NY: M.E. Sharpe.

Del Ángel-Mobarak, Gustavo. 2002. "Paradoxes of Financial Development: The Construction of the Mexican Banking System, 1941-1982." Ph.D. diss., Stanford University.

Del Ángel-Mobarak, Gustavo. 2005. "La banca mexicana antes de 1982.” In Gustavo del Ángel-Mobarak, Carlos Bazdresch, and Francisco Suárez Dávila, eds., Cuando el estado se hizo banquero: consecuencias de la nacionalización bancaria en México. Mexico City: Fondo de Cultura Económica.

Del Ángel-Mobarak, Gusatvo, Carlos Bazdresch, and Francisco Suárez Dávila, eds., 2005. Cuando el estado se hizo banquero: consecuencias de la nacionalización bancaria en México. Mexico City: Fondo de Cultura Económica. 
Del Ángel Mobarak, Gustavo, Stephen Haber and Aldo Musacchio. 2006. "Normas contables bancarias en México. Una guía de los cambios para legos diez años después de la crisis bancaria de 1995." El Trimestre Económico 73: 903-26.

Del Ángel Mobarak, Gustavo and César Martinelli Montoya. 2009. La Estatización de 1982 de la Banca en México: Un Ensayo en Economía Política. Mexico: Centro de Estudios Espinosa Yglesias, 2009.

Demirgüç-Kunt, Aslı and Enrica Detragiache, 2002. "Does Deposit Insurance Increase Banking System Stability? An Empirical Investigation.” Journal of Monetary Economics, 49: 1373-1406.

Demirgüç-Kunt, Asli, and Harry Huizinga. 2004. "Market Discipline and Deposit Insurance." Journal of Monetary Economics 51: 375-99.

Demirgüç-Kunt, Asli, and Edward J. Kane. 2002. "Deposit Insurance Around the Globe: Where Does It Work?” Journal of Economic Perspectives 16: 175-195.

Denizer, Cevdet. 1999. "Foreign Entry in Turkey’s Banking Sector, 1980-97.” World Bank Working Paper, Washington D.C.

Detragiache, Enrica, Theirry Tressel, and Poonam Gupta (2006). "Foreign Banks in Poor Countries: Theory and Evidence." Journal of Finance 63: 2123-60.

Engerman, Stanley and Kenneth L. Sokoloff, with contributions by Stephen Haber, Elisa Mariscal, and Eric Zolt. 2012. Economic Development in the Americas Since 1500: Endowments and Institutions. New York: Cambridge University Press.

Espinosa Rugarcía, Amparo, and Enrique Cárdenas Sánchez. 2011. Privatización bancaria, crisis y rescate del sistema financiero, Vol. 3. Mexico City: Centro de Estudios Espinosa Yglesias.

Galindo, Arturo, Alejandro Izquierdo, and Liliana Rojas-Suárez. 2010. "Financial Integration and Foreign Banks in Latin America: How do They Impact the Transmission of External Financial Shocks?” IDB Working paper 116.

Galindo, Arturo, Alejandro Micco, and Andrew Powell. 2004. "Loyal Lenders or Fickle Financiers: Foreign Banks in Latin America.” Working Paper 08/2004 Centro de Investigación en Finanzas, Universidad Torcuato di Tella.

Gonzalez-Hermosillo, Brenda, Pazarbasioglu, Ceyla, and Billings, Robert. 1997. "Determinants of Banking System Fragility: A Case Study of Mexico," IMF Staff Papers 44: 295-314. 
Gruben, William C., and Robert McComb. 1997. "Liberalization, Privatization, and Crash: Mexico's Banking System in the 1990s," Federal Reserve Bank of Dallas Economic Review First Quarter: 21-30.

Gruben, William C., and Robert McComb. 2003. "Privatization, Competition, and Supercompetition in the Mexican Commercial Banking System." Journal of Banking and Finance 27: 229-49.

Gruben, William C., and Welch, John H. 1996. "Distortions and Resolutions in Mexico's Financial system," in Laura Randall, ed., The Changing Structure of Mexico: Political, Social, and Economic Perspectives. Armonk, NY: ME Sharpe.

Gunther, Jeffrey W., Robert B. Moore, and Genie D. Short. 1996. "Mexican Banks and the 1994 Peso Crisis: The Importance of Initial Conditions," North American Journal of Economics and Finance 7: 125-33.

Haber, Stephen. 2005. "Mexico's Experiments with Bank Privatization and Liberalization, 1991-2003." Journal of Banking and Finance 29: 2325-53.

Haber, Stephen, and Aldo Musacchio. Forthcoming. "Foreign Entry and the Mexican Banking System, 1997-2007.” Economia.

Haber, Stephen, Douglass C. North and Barry R. Weingast. 2007. Political Institutions and Financial Development. Stanford: Stanford University Press.

Haber, Stephen, Armando Razo, and Noel Maurer. 2003. The Politics of Property Rights: Political Instability, Credible Commitments, and Economic Growth in Mexico, 18761929. New York: Cambridge University Press.

Havrylchyk, Olena. 2006. "Efficiency of the Polish Banking Industry: Foreign Versus Domestic Banks." Journal of Banking and Finance 30: 1975-96.

Ho, Thomas, and Anthony Saunders. 1981. "The Determinants of Bank Interest Margins: Theory and Empirical Evidence." Journal of Financial and Quantitative Analysis 4: 581-600.

IMF. 2006. International Financial Statistics Database. Washington, DC: IMF.

INEGI. 2009. Estadísticas históricas de México. 4th ed. Aguascalientes, Mexico: INEGI.

Izquierdo, Rafael. 1995. La política hacendaría del desarrollo estabilizador, 1958-1970. Mexico City: Fondo de Cultura Económica.

Knack, Stephen and Philip Keefer. 1995. "Institutions and Economic Performance: Cross Country Tests Using Alternative Institutional Measures." Economics and Politics 7: 207-27. 
Krueger, Anne O., and Aaron Tornell. 1999. "The Role of Bank Restructuring in Recovering from Crises: Mexico, 1995-1998.” National Bureau of Economic Research Working Paper no. 7042. Cambridge, MA: National Bureau of Economic Research.

Laeven, Luc, and Fabian Valencia. 2010. "Resolution of Banking Crises: The Good, the Bad, and the Ugly." IMF Working Paper.

La Porta, Rafael, Florencio López-de-Silanes, and Guillermo Zamarripa. 2003. "Related Lending." Quarterly Journal of Economics 118: 231-267.

Lees, Francis, James Botts, and Rubens Penha Cysne. 1991. Banking and Financial Deepening in Brazil. London: Palgrave Macmillan.

Lensink, Robert and Niels Hermes (2004). "The Short-Term Effects of Foreign Bank Entry on Domestic Bank Behaviour: Does Economic Development Matter?” Journal of Banking and Finance 28: 553-568.

Loaeza, Soledad. 2008. Las consequencias politicas de la expropiacion bancaria. Mexico: El Colegio de Mexico.

Ludlow, Leonor, and Carlos Marichal eds. 1985. Banca y poder en Mexico, 1800-1929. Mexico City: Editoral Grijalbo.

Mackey, Michael W. 1999. "Report of Michael W. Mackey on the Comprehensive Evaluation of the Operations and Function of the Fund for the Protection of Bank Savings (FOBAPROA) and the Quality of Supervision of the FOBAPROA Program, 19951998."

Magaloni, Beatriz. 2006. Voting for Autocracy: The Politics of Party Hegemony and its Demise in Mexico. New York: Cambridge University Press.

Mansell-Carstens, Catherine. 1996. "The Impact of Mexican Bank Privatizations," in William Glade ed., Bigger Economies, Smaller Governments: Privatization in Latin America. Boulder: Westview Press.

Martinez Peria, Maria Soledad and Ashoka Mody. 2004. "How Foreign Participation and Market Concentration Impact Bank Spreads: Evidence from Latin America." Journal of Money, Credit and Banking 36: 511-37.

Martínez Peria, María Soledad, and Sergio L. Schmukler. 2001. "Do Depositors Punish Banks for Bad Behavior? Market Discipline, Deposit Insurance, and Banking Crisis," Journal of Finance 56: 1029-51.

Maurer, Noel. 2002. The Power and the Money: The Mexican Financial System, 1876-1932. Stanford, CA: Stanford University Press. 
Maurer, Noel, and Andrei Gomberg. 2004. "When the State Is Untrustworthy: Public Finance and Private Banking in Porfirian Mexico." The Journal of Economic History 64: 10871107.

Maurer, Noel, and Stephen Haber. 2007. "Related Lending and Economic Performance: Evidence from Mexico.” The Journal of Economic History 67.

McQuerry, Elizabeth. 1999. "The Banking Sector Rescue in Mexico," Federal Reserve Bank of Atlanta Economic Review 84 (3): 14-29.

Mian, Atif. 2006. "Distance Constraints: The Limits of Foreign Lending in Poor Economies." Journal of Finance 61: 1465-1505.

Micco, Alejandro, and Eduardo Levy Yeyati. 2007. "Concentration and Foreign Penetration in Latin American Banking Sectors: Impact on Competition and Risk." Journal of Banking and Finance 31: 1633-47.

Mishkin, Frederic. 1996. "Understanding Financial Crises: A Developing Country Perspective.” National Bureau of Economic Research Working Paper no. 5600. Cambridge, MA: National Bureau of Economic Research.

Moreno-Brid, Juan Carlos, and Jame Ros. 2009. Development and Growth in the Mexican Economy: A Historical Perspective. Oxford: Oxford University Press.

Murillo, José Antonio. 2005. "La banca después de la privatización: auge, crisis y reordenamiento." In Gustavo del Ángel-Mobarak, Carlos Bazdresch, and Francisco Suárez Dávila, eds., Cuando el estado se hizo banquero: consecuencias de la nacionalización bancaria en México. Mexico City: Fondo de Cultura Económica.

Negrin, José Luis. 2000. "Mecanismos para compartir información crediticia: evidencia internacional y la experiencia mexicana." Dirección General de Investigación Económica, Banco de México, Working Paper no. 2000-05. Mexico City: Banco de México.

North, Douglass C., and Barry R. Weingast. 1989. "Constitutions and Commitment: The Evolution of Institutions Governing Public Choice in Seventeenth-Century England," The Journal of Economic History 49: 803-32.

Quintyn, Marc, and Genevieve Verdier. 2010. "Mother, May I Trust the Government? Sustained Financial Deepening - A Political Institutions View." IMF Working Paper $10 / 210$.

Smith, Peter H. 1991. "Mexico Since 1946: Dynamics of an Authoritarian Regime.” In Leslie Bethell, ed., Mexico Since Independence. New York: Cambridge University Press. 
Suárez Dávila, Francisco. 2010. La reprivatización bancaria fracasada: una tragedia nacional en tres actos. Mexico: Centro de Estudios Espinosa Yglesias.

Summerhill, William R. Forthcoming. Inglorious Revolution: Political Institutions, Sovereign Debt, and Financial Underdevelopment in Imperial Brazil (New Haven: Yale University Press).

Unal, Haluk, and Miguel Navarro. 1999. "The Technical Process of Bank Privatization in Mexico." Journal of Financial Services Research 16: 61-83.

Unite, Angelo A., and Michael J. Sullivan. 2003. "The Effect of Foreign Entry and Ownership Structure on the Philippine Domestic Banking Market." Journal of Banking and Finance 27: 2223-45.

Valdés Ugalde, Francisco. 1994. "From Bank Nationalization to State Reform: Business and the New Mexican Order." In Maria Lorena Cook, Kevin J. Middlebrook, and Juan Molinar Horcasitas, eds., The Politics of Economic Restructuring: State-Society Relations and Regime Change in Mexico. La Jolla, CA: Center for U.S.-Mexican Studies, University of California, San Diego.

Wong, Kit Pong. 1997. "On the Determinants of Bank Interest Margins under Credit and Interest Rate Risks." Journal of Banking and Finance 21: 251-71.

World Bank, Financial Structure Database, (November 2010 update).

Zarruck, Emilio R. 1989. "Bank Margin with Uncertain Deposits and Risk Aversion." Journal of Banking and Finance 14, 803-820. 


\section{Tables and Figures}

Table 1. Foreign Banks' Share of the Mexican Market (as a \% of Total Assets)

\begin{tabular}{cccc}
\hline & \multicolumn{3}{c}{ Foreign de } \\
Foreign M\&A & Novo & Total Foreign \\
\hline \hline 1991 & $0 \%$ & $1 \%$ & $1 \%$ \\
1992 & $0 \%$ & $1 \%$ & $1 \%$ \\
1993 & $0 \%$ & $3 \%$ & $3 \%$ \\
1994 & $0 \%$ & $4 \%$ & $4 \%$ \\
1995 & $3 \%$ & $2 \%$ & $5 \%$ \\
1996 & $4 \%$ & $3 \%$ & $7 \%$ \\
1997 & $7 \%$ & $4 \%$ & $11 \%$ \\
1998 & $11 \%$ & $9 \%$ & $20 \%$ \\
1999 & $11 \%$ & $8 \%$ & $20 \%$ \\
2000 & $55 \%$ & $2 \%$ & $57 \%$ \\
2001 & $50 \%$ & $5 \%$ & $54 \%$ \\
2002 & $79 \%$ & $2 \%$ & $82 \%$ \\
2003 & $79 \%$ & $3 \%$ & $82 \%$ \\
2004 & $79 \%$ & $4 \%$ & $83 \%$ \\
2005 & $79 \%$ & $4 \%$ & $83 \%$ \\
2006 & $77 \%$ & $5 \%$ & $82 \%$ \\
2007 & $75 \%$ & $5 \%$ & $80 \%$ \\
2008 & $70 \%$ & $5 \%$ & $74 \%$ \\
2009 & $70 \%$ & $4 \%$ & $74 \%$ \\
2010 & $58 \%$ & $9 \%$ & $67 \%$ \\
2011 & $65 \%$ & $9 \%$ & $74 \%$ \\
\hline \hline
\end{tabular}

Source: Estimated by the authors with data in Mexico. Comision Nacional Bancaria. Banca Multiple. Diciembre 1982-Diciembre 1993, Mexico: CNB, May 1994, for 1982-1993; Mexico. Comision Nacional Bancaria y de Valores (CNBV). Boletin Estadistico de Banca Multiple. Mexico: CNBV, December 1995, for 1992-1995; and, Boletin Estadistico de Banca Multiple available on-line at www.cnbv.gob.mx, accessed last on April 28, 2012, for 1995-2011. For the coding of Foreign banks see text. 
Figure 1. Foreign Banks' Share of the Mexican Market by Type of Bank (as a \% of Total Assets)

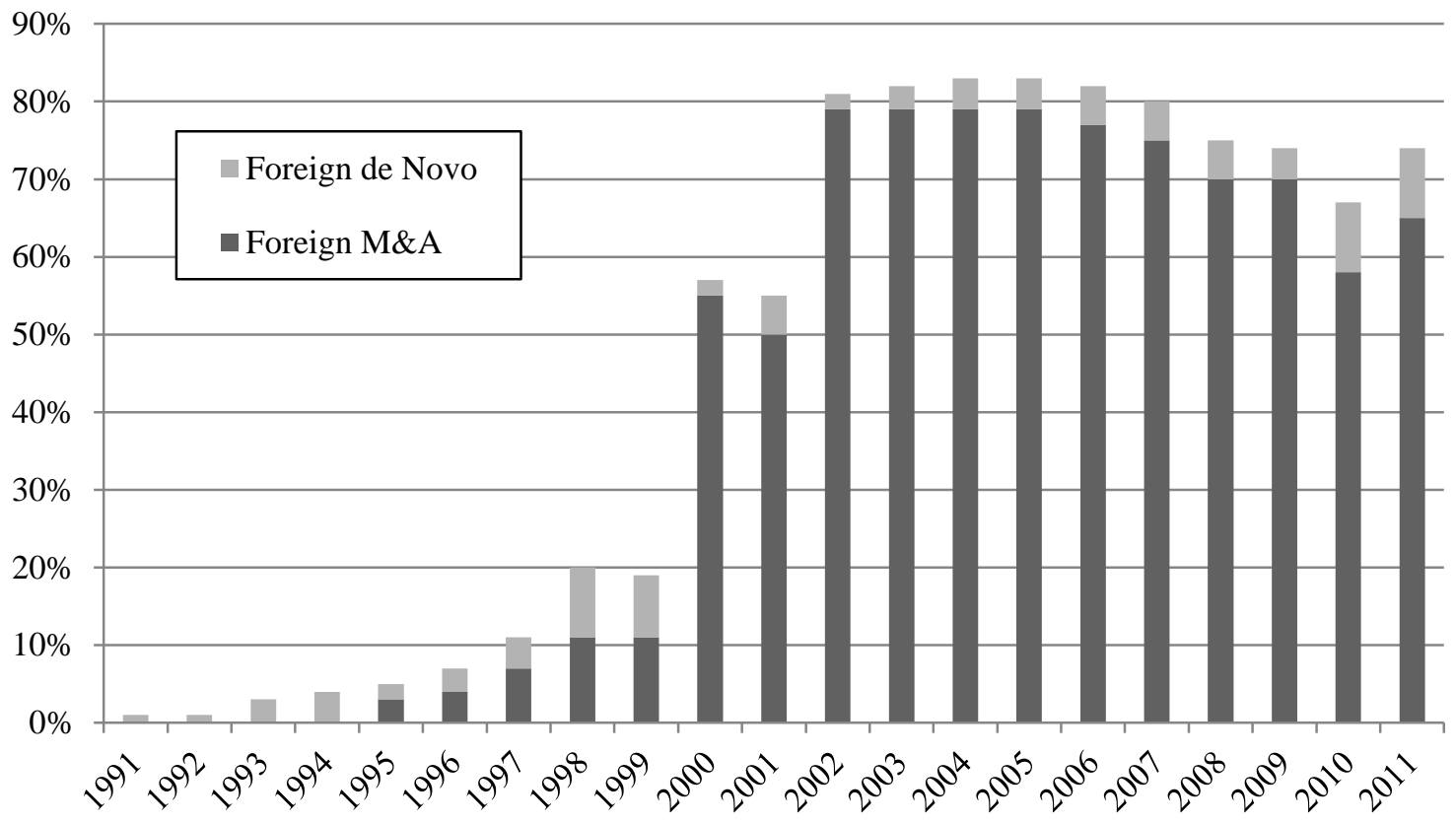

Source: See Table 1. 
Figure 2. The Sources of Credit in Mexico as a Percent of GDP, 1925-1978

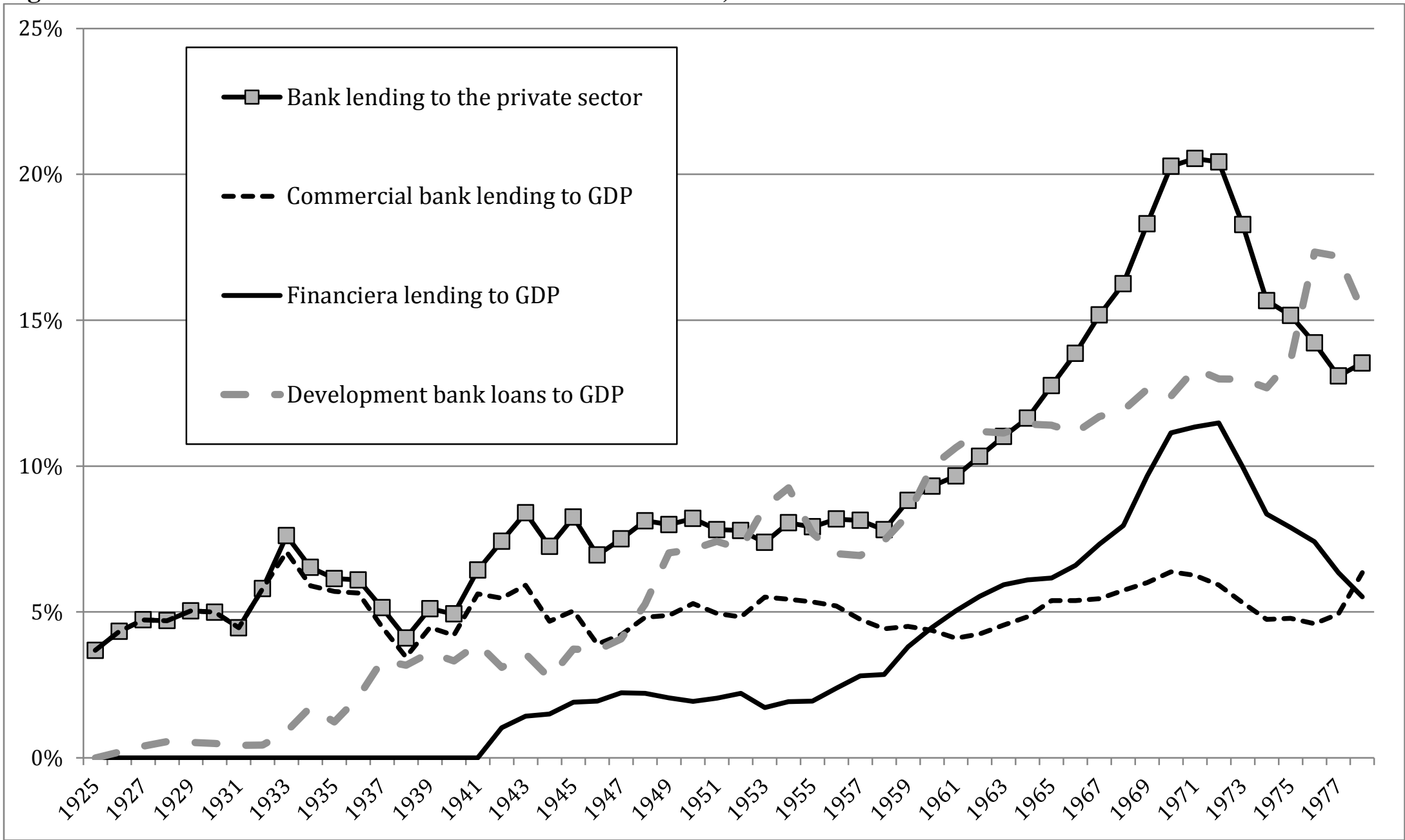

Source: INEGI and Del Angel Mobarak (2002). 
Figure 3

Credit to Firms and Households by Deposit Money Banks, as Percent of GDP, Upper Middle Income Countries, 2009

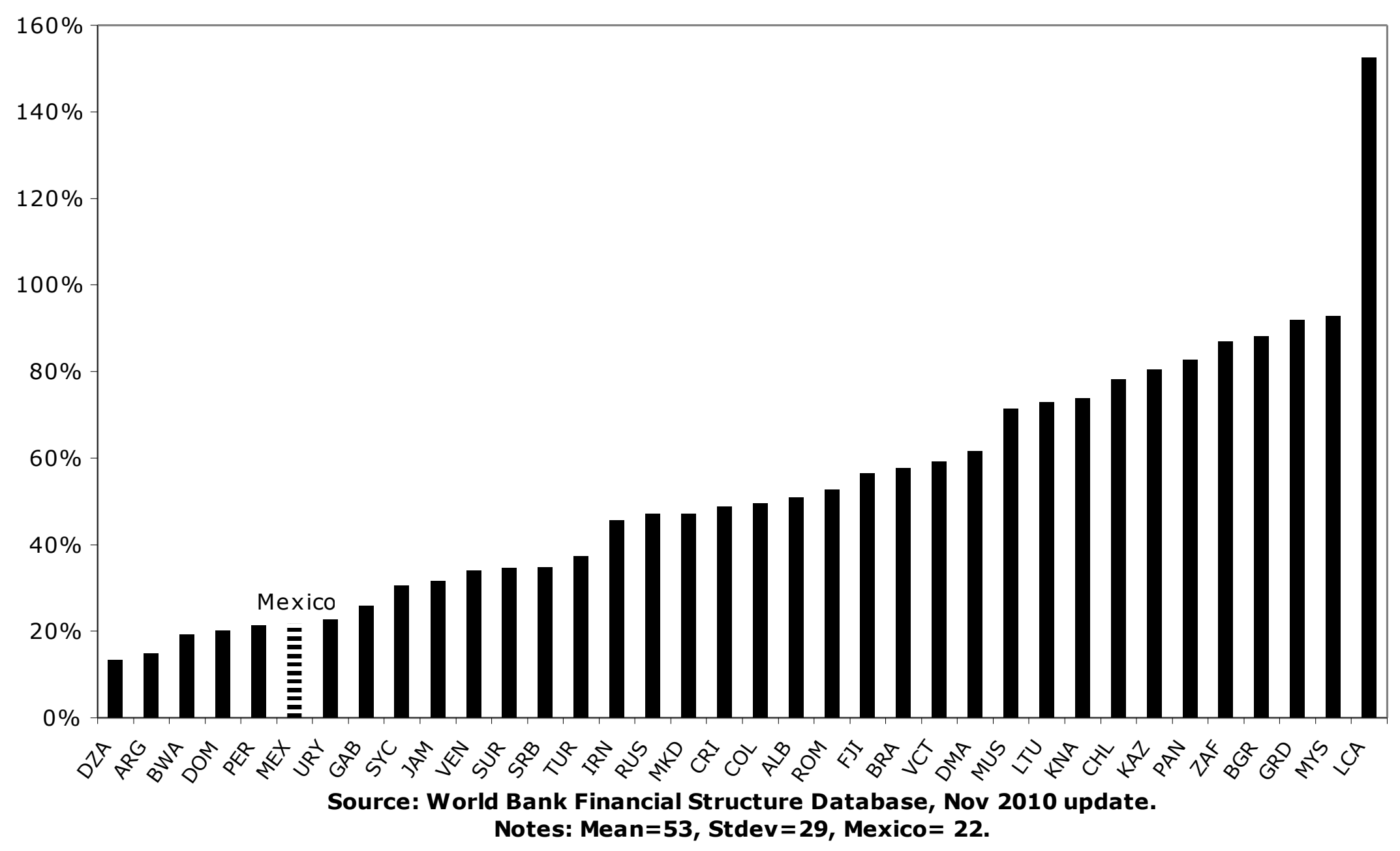


Table 2. Decomposing Bid to Book Ratios in Mexico's Bank Privatization

\begin{tabular}{|c|c|c|c|c|c|}
\hline & (1) & (2) & (3) & (4) & (5) \\
\hline Constant & $\begin{array}{c}2.66 \\
(7.32)\end{array}$ & $\begin{array}{c}6.57 \\
(4.65)\end{array}$ & $\begin{array}{c}4.95 \\
(4.02)\end{array}$ & $\begin{array}{c}3.7 \\
(2.74)\end{array}$ & $\begin{array}{c}4.1 \\
(2.30)\end{array}$ \\
\hline Log of Assets & & $\begin{array}{l}-0.33 \\
(-2.17)\end{array}$ & $\begin{array}{l}-0.31 \\
(-2.63)\end{array}$ & $\begin{array}{c}-0.3 \\
(-2.42)\end{array}$ & $\begin{array}{c}-0.2 \\
(-1.60)\end{array}$ \\
\hline Bid Round & $\begin{array}{c}0.25 \\
(2.70)\end{array}$ & & $\begin{array}{c}0.27 \\
(3.35)\end{array}$ & $\begin{array}{c}0.3 \\
(3.95)\end{array}$ & $\begin{array}{c}0.3 \\
(3.06)\end{array}$ \\
\hline $\begin{array}{l}\text { Number of } \\
\text { Bidders }\end{array}$ & & & $\begin{array}{c}0.17 \\
(1.44)\end{array}$ & $\begin{array}{c}0.2 \\
(1.93)\end{array}$ & $\begin{array}{c}0.2 \\
(1.55)\end{array}$ \\
\hline Return on Equity & & & & $\begin{array}{c}0.01 \\
(1.69)\end{array}$ & \\
\hline Return on Assets & & & & & $\begin{array}{c}0.1 \\
(0.63)\end{array}$ \\
\hline Observations & 18 & 18 & 18 & 18 & 18 \\
\hline Adjusted $\mathrm{R}^{2}$ & 0.27 & 0.18 & 0.49 & 0.55 & 0.47 \\
\hline Log likelihood & -17.89 & -18.95 & -13.38 & -11.59 & -13.11 \\
\hline Durbin-Watson & 1.37 & 1.13 & 1.79 & 1.44 & 1.69 \\
\hline F-statistic & 7.29 & 4.70 & 6.54 & 6.27 & 4.79 \\
\hline Prob(F-statistic) & 0.02 & 0.05 & 0.01 & 0.005 & 0.01 \\
\hline
\end{tabular}

Dependent variable is the price paid to book value of the bank. T-statistics are in parentheses. We ran these regressions using ordinary least squares.

Source: Data on assets, bid rounds, and number of bidders from Murillo (2002). Data on return on assets and return on equity calculated from data in Mexico, Commision Nacional Bancaria, Banca Multiple, 1982-1993. 
Table 3. Reported and Estimated Risk Profile of the Bank Loan Portfolios, 1991-2003

\begin{tabular}{cccccc} 
& $\begin{array}{c}\text { Declared non- } \\
\text { performing } \\
\text { (NPL) as } \\
\text { percent of total } \\
\text { loans }\end{array}$ & $\begin{array}{c}\text { Declared NPL } \\
\text { +rediscounts } \\
\text { as \% of total } \\
\text { loans }\end{array}$ & $\begin{array}{c}\text { Declared NPL }+ \\
\text { rediscounts }+ \\
\text { renewed and } \\
\text { restructured as } \% \\
\text { of total loans }\end{array}$ & $\begin{array}{c}\text { FOBAPROA } \\
\text { or IPAB as } \% \\
\text { of total loans }\end{array}$ & $\begin{array}{c}\text { Declared NPL + } \\
\text { rediscounts + } \\
\text { restructured and } \\
\text { FOBAPROA-IPAB } \\
\text { as \% of total loans }\end{array}$ \\
\hline \hline 1991 & $3.6 \%$ & $13.5 \%$ & $13.5 \%$ & $0 \%$ & $13.5 \%$ \\
1992 & $4.7 \%$ & $14.7 \%$ & $14.7 \%$ & $0 \%$ & $14.7 \%$ \\
1993 & $6.0 \%$ & $16.2 \%$ & $16.2 \%$ & $0 \%$ & $16.2 \%$ \\
1994 & $6.1 \%$ & $17.1 \%$ & $17.1 \%$ & $0 \%$ & $17.1 \%$ \\
1995 & $6.2 \%$ & $13.3 \%$ & $26.8 \%$ & $9.5 \%$ & $36.3 \%$ \\
1996 & $5.7 \%$ & $10.8 \%$ & $32.5 \%$ & $20.1 \%$ & $52.6 \%$ \\
1997 & $10.2 \%$ & $10.2 \%$ & $10.2 \%$ & $28.9 \%$ & $39.0 \%$ \\
1998 & $10.2 \%$ & $10.2 \%$ & $10.2 \%$ & $29.5 \%$ & $39.7 \%$ \\
1999 & $8.2 \%$ & $8.2 \%$ & $8.2 \%$ & $35.3 \%$ & $43.5 \%$ \\
2000 & $5.5 \%$ & $5.5 \%$ & $5.5 \%$ & $28.9 \%$ & $34.4 \%$ \\
2001 & $4.9 \%$ & $4.9 \%$ & $4.9 \%$ & $27.8 \%$ & $32.7 \%$ \\
2002 & $4.4 \%$ & $4.4 \%$ & $4.4 \%$ & $22.7 \%$ & $27.1 \%$ \\
2003 & $3.2 \%$ & $3.2 \%$ & $3.2 \%$ & $21.0 \%$ & $24.1 \%$ \\
\hline \hline
\end{tabular}

Source: Calculated from data in Mexico. Comisión Nacional Bancaria. Banca Múltiple.1982-93, and Mexico. Comisión Nacional Bancaria y de Valores, Boletín Estadístico de Banca Múltiple, 1993-2004.

Note: Reported nonperforming loans (NPL) includes only past due interest until at least 1997. After 1997 this figures include the principal as well. Yet NPLs cleaned as part of the FOBAPROA bailout program are not included in this reported figure. Thus, in the last column we estimate total nonperforming loans as the sum of the declared NPL, rediscounts, restructured loans, and the total sum of the FOBAPROA bonds. 
Table 4

Mexican Bank Lending, By Category (Balances at Year End in Millions of Pesos of Dec 2000)

\begin{tabular}{|c|c|c|c|c|c|c|c|c|}
\hline Year & Commercial $^{1}$ & Consumer & Housing & Government $^{2}$ & $\begin{array}{c}\text { Fobaproa } \\
\text { and } \mathrm{IPAB}^{3}\end{array}$ & $\begin{array}{c}\text { Renewed, } \\
\text { Restructured, or } \\
\text { Rediscounted }^{4}\end{array}$ & $\begin{array}{l}\text { Loans to other } \\
\text { financial } \\
\text { institutions }\end{array}$ & $\begin{array}{c}\text { Total Private } \\
\text { Lending }^{5}\end{array}$ \\
\hline 1991 & 776,386 & 91,312 & 114,805 & & & 112,256 & & 982,503 \\
\hline 1992 & 961,879 & 127,757 & 178,439 & & & 148,728 & & $1,268,075$ \\
\hline 1993 & $1,181,744$ & 118,880 & 248,808 & & & 187,766 & & $1,549,432$ \\
\hline 1994 & $1,423,325$ & 109,387 & 299,437 & & & 244,066 & & $1,832,149$ \\
\hline 1995 & 801,937 & 51,617 & 192,304 & 957 & 156,237 & 339,796 & & $1,045,858$ \\
\hline 1996 & 513,686 & 27,745 & 80,338 & 18,587 & 273,760 & 364,298 & & 621,769 \\
\hline 1997 & 405,675 & 39,415 & 173,251 & 88,181 & 340,212 & & & 618,341 \\
\hline 1998 & 354,414 & 30,634 & 150,547 & 88,647 & 218,779 & & 15,357 & 550,952 \\
\hline 1999 & 276,297 & 31,665 & 125,478 & 89,016 & 353,099 & & 15,777 & 449,217 \\
\hline 2000 & 296,442 & 38,650 & 109,178 & 144,118 & 364,893 & & 11,973 & 456,243 \\
\hline 2001 & 285,394 & 54,359 & 111,362 & 147,899 & 265,011 & & 16,946 & 468,061 \\
\hline 2002 & 294,192 & 71,372 & 113,484 & 186,825 & 245,804 & & 24,022 & 503,070 \\
\hline 2003 & 274,055 & 99,075 & 99,591 & 178,975 & 240,955 & & 21,918 & 494,639 \\
\hline 2004 & 306,640 & 135,968 & 99,191 & 132,354 & 165,395 & & 34,574 & 576,373 \\
\hline 2005 & 325,805 & 202,868 & 135,183 & 147,693 & 148,334 & & 46,853 & 710,709 \\
\hline 2006 & 385,313 & 273,367 & 170,112 & 121,348 & 38,439 & & 41,392 & 870,184 \\
\hline 2007 & 489,207 & 120,811 & 327,787 & 192,427 & 15,459 & & 59,136 & 996,941 \\
\hline 2008 & 402,801 & 294,814 & 197,052 & 100,176 & & & 52,823 & 947,490 \\
\hline 2009 & 388,043 & 233,653 & 213,375 & 152,240 & & & 42,654 & 877,725 \\
\hline 2010 & 359,313 & 179,731 & 191,109 & 186,964 & & & 40,789 & 770,942 \\
\hline 2011 & 428,518 & 213,641 & 230,311 & 199,854 & & & 41,039 & 913,509 \\
\hline
\end{tabular}

Notes:

1) The commercial loan category did not exist before 1997, thus it was estimated as a residual of total loans minus consumer, housing, government, restructured and renewed and non-performing loans.

2) Does not include government bonds, which are held in the securities portfolio.

3) Value of Fobaproa and IPAB promissory notes held by banks. They are treated as loans, because they represent loans transferred to Fobaproa and IPAB.

4) Rediscounted loans are non-performing loans whose principal was rolled over. Restructured and Renewed represent loans in danger of default. In 1997, new accounting standards required banks to either declare these as non-performing or treat them as performing loans.

5) Includes Commercial, Consumer, and Housing.

Source: Aggregates created by the authors from the loan portfolios ("Carteras de Credito") published in Comisión Nacional Bancaria. Banca Multiple, 1982-1993 and Comisión Nacional Bancaria y de Valores. Boletin Estadístico de Banca Múltiple, 1993-2011. We deflate the data using the wholesale Price index from the Banco de México web page (December 2000=100), available at http://www.banxico.org, accessed May 12, 2012. 
Table 5. Equity Ratios (non-risk weighted), by Bank Type, Mexico, 1997-2011

\begin{tabular}{ccccc}
\hline & All Banks & Domestic & DeNovo & Foreign MA \\
\hline \hline 1997 & $9 \%$ & $9 \%$ & $10 \%$ & $4 \%$ \\
1998 & $9 \%$ & $9 \%$ & $10 \%$ & $7 \%$ \\
1999 & $10 \%$ & $10 \%$ & $10 \%$ & $8 \%$ \\
2000 & $10 \%$ & $13 \%$ & $21 \%$ & $7 \%$ \\
2001 & $10 \%$ & $12 \%$ & $10 \%$ & $8 \%$ \\
2002 & $11 \%$ & $13 \%$ & $10 \%$ & $10 \%$ \\
2003 & $11 \%$ & $12 \%$ & $11 \%$ & $11 \%$ \\
2004 & $11 \%$ & $13 \%$ & $11 \%$ & $10 \%$ \\
2005 & $12 \%$ & $14 \%$ & $12 \%$ & $12 \%$ \\
2006 & $13 \%$ & $14 \%$ & $10 \%$ & $13 \%$ \\
2007 & $13 \%$ & $13 \%$ & $10 \%$ & $14 \%$ \\
2008 & $10 \%$ & $9 \%$ & $10 \%$ & $10 \%$ \\
2009 & $11 \%$ & $10 \%$ & $15 \%$ & $11 \%$ \\
2010 & $11 \%$ & $10 \%$ & $9 \%$ & $11 \%$ \\
2011 & $10 \%$ & $10 \%$ & $15 \%$ & $11 \%$ \\
\hline \hline
\end{tabular}

Source: Calculated by the authors from Mexico. CNBV. Boletin Estadistico de Banca Multiple, available on-line at www.cnbv.org, accessed April 28, 2012. 
Table 6. Non-Performing Loan Ratio by Bank Type, 1997-2011

\begin{tabular}{rrrrr}
\hline & All Banks & Domestic & DeNovo & Foreign MA \\
\hline \hline 1997 & $11 \%$ & $12 \%$ & $3 \%$ & $4 \%$ \\
1998 & $10 \%$ & $12 \%$ & $2 \%$ & $2 \%$ \\
1999 & $8 \%$ & $9 \%$ & $2 \%$ & $2 \%$ \\
2000 & $6 \%$ & $4 \%$ & $1 \%$ & $5 \%$ \\
2001 & $4 \%$ & $5 \%$ & $2 \%$ & $4 \%$ \\
2002 & $5 \%$ & $3 \%$ & $2 \%$ & $5 \%$ \\
2003 & $3 \%$ & $2 \%$ & $1 \%$ & $4 \%$ \\
2004 & $3 \%$ & $1 \%$ & $1 \%$ & $3 \%$ \\
2005 & $2 \%$ & $1 \%$ & $2 \%$ & $2 \%$ \\
2006 & $2 \%$ & $2 \%$ & $2 \%$ & $2 \%$ \\
2007 & $3 \%$ & $2 \%$ & $3 \%$ & $3 \%$ \\
2008 & $3 \%$ & $2 \%$ & $4 \%$ & $3 \%$ \\
2009 & $3 \%$ & $3 \%$ & $5 \%$ & $3 \%$ \\
2010 & $3 \%$ & $2 \%$ & $4 \%$ & $3 \%$ \\
2011 & $2 \%$ & $3 \%$ & $2 \%$ & $2 \%$ \\
\hline \hline
\end{tabular}

Source: Calculated by the authors from Mexico. CNBV. Boletin Estadistico de Banca Multiple, available online at www.cnbv.org, accessed April 28, 2012. 
Table 7. Returns of Banks in Mexico, 1997-2011

\begin{tabular}{ccccc|cccc}
\hline & \multicolumn{3}{c}{ Return on assets (ROA) in \% } & \multicolumn{4}{c}{ Return on equity (ROE) in \% } \\
\cline { 3 - 8 } & All banks & Domestic & $\begin{array}{c}\text { Foreign } \\
\text { MA }\end{array}$ & $\begin{array}{c}\text { Foreign } \\
\text { DeNovo }\end{array}$ & All banks & Domestic & $\begin{array}{c}\text { Foreign } \\
\text { MA }\end{array}$ & $\begin{array}{c}\text { Foreign } \\
\text { DeNovo }\end{array}$ \\
\hline \hline 1997 & 0.1 & 0.2 & -0.3 & -0.8 & 1.0 & 2.3 & -3.1 & -20.8 \\
1998 & 0.5 & 0.7 & -0.1 & -0.3 & 6.9 & 8.9 & -0.8 & -15.4 \\
1999 & 0.1 & 0.0 & 0.4 & 1.0 & 1.2 & -0.4 & 3.6 & 13.7 \\
2000 & 0.9 & 1.7 & -0.7 & 0.3 & 8.8 & 9.6 & -1.8 & 11.1 \\
2001 & 1.0 & 0.8 & 0.6 & 1.2 & 10.4 & 6.9 & 7.8 & 15.4 \\
2002 & 0.5 & 1.5 & -0.2 & 0.4 & 5.2 & 4.5 & -2.1 & 6.7 \\
2003 & 1.4 & 0.7 & 0.8 & 1.6 & 12.7 & 5.8 & 8.9 & 14.5 \\
2004 & 1.2 & 1.2 & 0.2 & 1.3 & 12.0 & 9.6 & 2.5 & 13.0 \\
2005 & 2.2 & 2.0 & 1.3 & 2.3 & 18.7 & 14.2 & 11.5 & 20.3 \\
2006 & 2.5 & 1.7 & 0.8 & 2.8 & 20.1 & 12.4 & 8.3 & 22.8 \\
2007 & 2.1 & 1.5 & 0.6 & 2.3 & 15.9 & 11.3 & 6.1 & 17.6 \\
2008 & 1.2 & 1.0 & 1.1 & 1.3 & 12.2 & 11.9 & 12.3 & 12.4 \\
2009 & 1.3 & 1.1 & 0.5 & 1.6 & 12.9 & 11.5 & 5.6 & 14.7 \\
2010 & 1.3 & 1.3 & 0.3 & 1.5 & 11.8 & 12.6 & 3.6 & 13.0 \\
2011 & 1.2 & 1.2 & 0.3 & 1.5 & 12.3 & 12.0 & 4.5 & 13.9 \\
\hline \hline
\end{tabular}

Source: Calculated by the authors from Mexico. Comision Nacional Bancaria. Banca Multiple. Diciembre 1982-Diciembre 1993 CNB, May 1994, for 1982-1993; Mexico. Comision Nacional Bancaria y de Valores.

Boletin Estadistico de Banca Multiple. CNBV, December 1995, for 1992-1995; and, the Boletin Estadistico de Banca Multiple available on-line at www.cnbv.org, accessed April 28, 2012. 
Table 8. Banks Operating in Mexico, by Ownership Type, September 1997 to December 2011

\begin{tabular}{|c|c|c|c|c|c|c|c|c|}
\hline \multirow{2}{*}{$\begin{array}{l}\text { Domestically } \\
\text { owned bank } \\
\text { Amigo }\end{array}$} & \multicolumn{2}{|c|}{$\begin{array}{l}\text { Dates in sample } \\
\text { (year:quarter) }\end{array}$} & \multirow{2}{*}{$\frac{\text { Foreign de novo bank }^{b}}{\text { ABN AMRO/Roval Bank of Scotland }}$} & \multicolumn{2}{|c|}{$\begin{array}{c}\text { Dates in sample } \\
\text { (year:quarter) }\end{array}$} & \multirow{2}{*}{$\begin{array}{c}\text { Foreign MA bank }{ }^{a} \\
\text { (Acquirer - Acquired bank) } \\
\text { BBVA - Bancomer }\end{array}$} & \multicolumn{2}{|c|}{$\begin{array}{c}\text { Dates in sample } \\
\text { (year:quarter) }\end{array}$} \\
\hline & $2007: 3$ & $2011: 4$ & & $1997: 3$ & $2011: 4$ & & $2000: 4$ & $2011: 4$ \\
\hline Ahorro Famsa & 2007:1 & 2011:4 & American Express & $1997: 4$ & 2011:4 & Citibank - Banamex & $2002: 4$ & 2011:4 \\
\hline Autofin & $2006: 4$ & 2011:4 & Ve Por Mas (former Dresdner Bank) & $2004: 2$ & 2011:4 & GE Capital Bank - Alianza & $1997: 4$ & 2011:4 \\
\hline Afirme & 1997.3 & 2011:4 & Bank of America & $1997: 3$ & 2011:4 & HSBC - Bital & 2002:4 & 2011:4 \\
\hline Banamex & $1997: 3$ & 2002:3 & Bank One & 1998:1 & $2004: 3$ & Santander - Banco Mexicano & $1997: 4$ & 2004:4 \\
\hline BANCEN & 1997:3 & 2006:2 & BankBoston & $1997: 3$ & 2004:2 & Santander Mexicano - Serfin & 2000:3 & 2011:4 \\
\hline Banco Azteca & $2002: 4$ & $2011: 4$ & BNP Mexico & $1997: 3$ & $2000: 4$ & Scotiabank Inverlat - Inverlat & $2000: 4$ & 2011:4 \\
\hline Bancomer & $1997: 3$ & 2000:3 & Chase Manhattan & $1997: 3$ & 2001:1 & & & \\
\hline Bancoppel & $2007: 3$ & 2011:4 & Citibank & $1997: 4$ & 1998:3 & & & \\
\hline Banortee $^{c}$ & $1997: 3$ & 2011:4 & Comerica/ Monex & $1997: 3$ & $2011: 4$ & & & \\
\hline Banpaís & 1998:1 & 1999:4 & Deustche & 2000:4 & 2001:4 & & & \\
\hline BanRegio & $1997: 3$ & 2011:4 & Dresdner Bank & $1997: 3$ & 2003:2 & & & \\
\hline Bansí & $1997: 3$ & 2011:4 & HSBC & $1997: 3$ & 2003:1 & & & \\
\hline Bital & $1997: 3$ & $2002: 3$ & ING Bank & $1997: 3$ & $2011: 4$ & & & \\
\hline Compartamos & 2006:2 & 2011:3 & J. P. Morgan & $1997: 3$ & 2011:4 & & & \\
\hline Del Bajío & 1997:3 & 2011:4 & BBVA/ Probursa (Acquired 1995) & $1997: 3$ & $2000: 3$ & & & \\
\hline Fácil & $2007: 3$ & 2011:4 & Prudential/Actinver & 2008:1 & 2011:4 & & & \\
\hline Inbursa & $1997: 3$ & 2011:4 & Nations Bank & $1997: 3$ & 1998:4 & & & \\
\hline Interacciones & 1997:3 & 2011:4 & Société Générale & 1997:3 & 1999:4 & & & \\
\hline Invex & 1997:3 & 2011:4 & Tokio Mitsubishi & 1997:3 & 2011:4 & & & \\
\hline IXE & 1997:3 & 2011:4 & & & & & & \\
\hline Mifel & $1997: 3$ & 2011:4 & & & & & & \\
\hline Multiva & 2007:2 & 2011:4 & & & & & & \\
\hline Regional & 2008:4 & 2011:4 & & & & & & \\
\hline Quadrum & $1997: 3$ & 2001:3 & & & & & & \\
\hline Serfin & 1997:3 & 2000:2 & & & & & & \\
\hline
\end{tabular}

a. We code Mexican banks as foreign MA banks on the date that the merged bank began to operate.

b. For some of our econometric analysis we excluded the observations of ABN Amro/RBS, JP Morgan, and Bank of America, and Deutsche Bank because of the volatile way in which they reported interest income.

c. Banorte since December of 2008 reports its financials as Banco Mercantil del Norte. 
Table 9. Summary Statistics of the Mexican Banking System, September 1997-December 2011

\begin{tabular}{|c|c|c|c|c|c|c|c|c|c|c|c|c|}
\hline \multirow[b]{2}{*}{ Variable } & \multicolumn{3}{|c|}{$\underline{\text { All Banks }}$} & \multicolumn{3}{|c|}{ Domestic Banks } & \multicolumn{3}{|c|}{$\underline{\text { Foreign M\&A }}$} & \multicolumn{3}{|c|}{$\underline{\text { Foreign De Novo }}$} \\
\hline & $\mathrm{N}$ & mean & sd & $\mathrm{N}$ & mean & sd & $\mathrm{N}$ & mean & sd & $\mathrm{N}$ & mean & sd \\
\hline Assets (current P\$) & 1747 & 81602.25 & 177638.60 & 876 & 50198 & 93781 & 289 & 291684 & 316928 & 582 & 24552 & 71371 \\
\hline NIM & 1742 & 0.029 & 0.074 & 876 & 0.030 & 0.055 & 289 & 0.019 & 0.029 & 577 & 0.032 & 0.106 \\
\hline $\operatorname{ROA}(\%)$ & 1747 & -0.001 & 0.023 & 876 & 0.001 & 0.024 & 289 & 0.002 & 0.007 & 582 & -0.005 & 0.027 \\
\hline ROE (\%) & 1747 & 0.010 & 0.083 & 876 & 0.015 & 0.091 & 289 & 0.026 & 0.064 & 582 & -0.005 & 0.078 \\
\hline Cash/assets & 1747 & 0.160 & 0.129 & 876 & 0.135 & 0.098 & 289 & 0.157 & 0.068 & 582 & 0.199 & 0.175 \\
\hline admin costs/assets & 1747 & 0.030 & 0.054 & 876 & 0.032 & 0.047 & 289 & 0.023 & 0.030 & 582 & 0.032 & 0.071 \\
\hline NPL/Loans & 1747 & 0.034 & 0.066 & 876 & 0.043 & 0.067 & 289 & 0.031 & 0.026 & 582 & 0.022 & 0.077 \\
\hline Equity ratio & 1747 & 0.176 & 0.154 & 876 & 0.172 & 0.154 & 289 & 0.141 & 0.105 & 582 & 0.199 & 0.169 \\
\hline Housing loans/assets & 1710 & 0.037 & 0.090 & 869 & 0.039 & 0.083 & 287 & 0.085 & 0.108 & 554 & 0.009 & 0.077 \\
\hline FOBAPROA loans/assets & 1184 & 0.060 & 0.144 & 567 & 0.072 & 0.174 & 217 & 0.109 & 0.140 & 400 & 0.016 & 0.066 \\
\hline Commercial loans/assets & 1710 & 0.307 & 0.237 & 869 & 0.359 & 0.236 & 287 & 0.236 & 0.168 & 554 & 0.261 & 0.250 \\
\hline Consumer loans/assets & 1710 & 0.090 & 0.204 & 869 & 0.099 & 0.214 & 287 & 0.088 & 0.116 & 554 & 0.077 & 0.224 \\
\hline
\end{tabular}

Note: We exclude observations from our analysis when banks had net interest margins above $100 \%$ or below $-100 \%$. 
Table 10. Net Interest Margins Regressions

\begin{tabular}{|c|c|c|c|}
\hline VARIABLES & $\begin{array}{c}1 \\
\text { NIMs } \\
\text { Random Effects }\end{array}$ & $\begin{array}{c}2 \\
\text { NIMs } \\
\text { Random Effects }\end{array}$ & $\begin{array}{c}\text { NIMs } \\
\text { Fixed Effects }\end{array}$ \\
\hline Foreign MA dummy & $\begin{array}{l}-0.008 \\
(0.005)\end{array}$ & $\begin{array}{l}-0.009 * \\
(0.005)\end{array}$ & $\begin{array}{c}0.001 \\
(0.005)\end{array}$ \\
\hline Foreign MA $*$ trend & $\begin{array}{l}-0.000 \\
(0.000)\end{array}$ & & \\
\hline Foreign De Novo dummy & $\begin{array}{c}-0.019 * * \\
(0.008)\end{array}$ & $\begin{array}{c}-0.014 * * \\
(0.005)\end{array}$ & $\begin{array}{l}-0.009 \\
(0.006)\end{array}$ \\
\hline Foreign De Novo $*$ trend & $\begin{array}{c}0.000 \\
(0.000)\end{array}$ & & \\
\hline Trend & $\begin{array}{c}0.000 \\
(0.000)\end{array}$ & & \\
\hline Cash over assets & $\begin{array}{l}-0.025 \\
(0.021)\end{array}$ & $\begin{array}{l}-0.029 \\
(0.022)\end{array}$ & $\begin{array}{l}-0.012 \\
(0.017)\end{array}$ \\
\hline Admin costs over assets & $\begin{array}{l}0.456 * \\
(0.250)\end{array}$ & $\begin{array}{c}0.346 \\
(0.254)\end{array}$ & $\begin{array}{c}0.057 \\
(0.345)\end{array}$ \\
\hline NPL over loans & $\begin{array}{l}-0.064 \\
(0.045)\end{array}$ & $\begin{array}{l}-0.056 \\
(0.046)\end{array}$ & $\begin{array}{l}-0.036 \\
(0.048)\end{array}$ \\
\hline Equity Ratio & $\begin{array}{l}-0.038 * \\
(0.023)\end{array}$ & $\begin{array}{l}-0.045^{*} \\
(0.024)\end{array}$ & $\begin{array}{l}-0.084 * \\
(0.047)\end{array}$ \\
\hline Housing loans over assets & $\begin{array}{c}0.027 \\
(0.037)\end{array}$ & $\begin{array}{c}0.035 \\
(0.035)\end{array}$ & $\begin{array}{l}-0.047 \\
(0.029)\end{array}$ \\
\hline FOBAPROA loans over assets & $\begin{array}{c}-0.019 * * \\
(0.009)\end{array}$ & $\begin{array}{l}-0.020 * \\
(0.011)\end{array}$ & $\begin{array}{l}-0.018 \\
(0.034)\end{array}$ \\
\hline Commercial loans over assets & $\begin{array}{l}-0.010 \\
(0.011)\end{array}$ & $\begin{array}{l}-0.010 \\
(0.011)\end{array}$ & $\begin{array}{l}-0.019 \\
(0.014)\end{array}$ \\
\hline Consumer loans over assets & $\begin{array}{l}0.062 * * \\
(0.024)\end{array}$ & $\begin{array}{c}0.064 * * * \\
(0.022)\end{array}$ & $\begin{array}{c}0.013 \\
(0.022)\end{array}$ \\
\hline Constant & $\begin{array}{r}0.017 \\
(0.012) \\
\end{array}$ & $\begin{array}{l}0.023 * * \\
(0.011)\end{array}$ & $\begin{array}{l}0.047 * * \\
(0.019)\end{array}$ \\
\hline Observations & 1,035 & 1,039 & 1,039 \\
\hline Number of banks & 40 & 41 & 41 \\
\hline $\mathrm{R} 2$ overall & 0.41 & 0.35 & 0.13 \\
\hline $\mathrm{R} 2$ between & 0.45 & 0.50 & 0.02 \\
\hline R2 within & 0.13 & 0.09 & 0.16 \\
\hline Chi2 (RE)/F-stat(FE) & 98.63 & 34.26 & 6.927 \\
\hline Chi2/F p value & 0.00 & 0.00 & 0.00 \\
\hline AR1-test F stat & 0.03 & 0.28 & 0.28 \\
\hline AR1-test pval & 0.86 & 0.60 & 0.60 \\
\hline
\end{tabular}

Dependent variable is net interest margins (NIMs), where NIMs equal interest and commissions on loans over total loans minus interest and commissions paid on deposits over total deposits. . The sample goes from September 1997 to December 2011. All estimations include quarterly dummies. Robust Standard Errors clustered at the bank level. Significance of 1,5 , and 10 per cent denoted by ***, **, and *, respectively. 


\section{Table 11. Nonperforming Loan Regressions}

\begin{tabular}{|c|c|c|}
\hline & $\begin{array}{c}1 \\
\text { NPLs } \\
\text { Random } \\
\text { Effects } \\
\end{array}$ & $\begin{array}{c}2 \\
\text { NPLs } \\
\text { Bank Fixed } \\
\text { Effects } \\
\end{array}$ \\
\hline Foreign MA dummy & $\begin{array}{c}-0.017 \\
(0.014)\end{array}$ & $\begin{array}{c}-0.065 * * * \\
(0.021)\end{array}$ \\
\hline Foreign MA * trend & $\begin{array}{c}-0.000 \\
(0.000)\end{array}$ & \\
\hline Foreign De Novo dummy & $\begin{array}{c}-0.071 * * * \\
(0.020)\end{array}$ & $\begin{array}{c}-0.078 * * * \\
(0.022)\end{array}$ \\
\hline Foreign De Novo * trend & $\begin{array}{c}0.002 * * * \\
(0.000)\end{array}$ & \\
\hline Trend & $\begin{array}{c}-0.000 * \\
(0.000)\end{array}$ & \\
\hline Cash over assets & $\begin{array}{c}0.075 \\
(0.080)\end{array}$ & $\begin{array}{c}0.064 \\
(0.094)\end{array}$ \\
\hline Admin costs over assets & $\begin{array}{l}-0.345 \\
(0.388)\end{array}$ & $\begin{array}{c}0.477 \\
(0.384)\end{array}$ \\
\hline Equity Ratio & $\begin{array}{l}0.123^{*} \\
(0.073)\end{array}$ & $\begin{array}{l}0.116^{*} \\
(0.062)\end{array}$ \\
\hline FOBAPROA loans over assets & $\begin{array}{c}0.061 \\
(0.072)\end{array}$ & $\begin{array}{c}0.003 \\
(0.160)\end{array}$ \\
\hline Housing loans over assets & $\begin{array}{c}0.137 * * * \\
(0.051)\end{array}$ & $\begin{array}{c}0.081 * \\
(0.046)\end{array}$ \\
\hline Commercial loans over assets & $\begin{array}{c}-0.054 \\
(0.048)\end{array}$ & $\begin{array}{c}-0.058 \\
(0.046)\end{array}$ \\
\hline Consumer loans over assets & $\begin{array}{c}0.032 \\
(0.030)\end{array}$ & $\begin{array}{c}0.030 \\
(0.070)\end{array}$ \\
\hline Constant & $\begin{array}{c}0.039 \\
(0.033)\end{array}$ & $\begin{array}{c}0.037 \\
(0.056)\end{array}$ \\
\hline Observations & 1,035 & 1,039 \\
\hline Number of banks & 40 & 41 \\
\hline R2 overall & 0.27 & 0.09 \\
\hline $\mathrm{R} 2$ between & 0.21 & 0.00 \\
\hline R2 within & 0.17 & 0.20 \\
\hline
\end{tabular}

Dependent variable is nonperforming loans to total loans. . The sample goes from September 1997 to December 2011. All estimations include quarterly dummies. Robust Standard Errors clustered at the bank level.

Significance of 1,5 , and 10 per cent denoted by $* * *, * *$, and $*$, respectively. 
Table 12. Private Lending Regressions

\begin{tabular}{|c|c|c|c|}
\hline VARIABLES & $\begin{array}{c}1 \\
\text { Private credit } \\
\text { Random effects } \\
\text { with trends } \\
\end{array}$ & $\begin{array}{c}2 \\
\text { Private credit } \\
\text { Random effects } \\
\text { without trends } \\
\end{array}$ & $\begin{array}{c}3 \\
\text { Private credit } \\
\text { Fixed effects } \\
\end{array}$ \\
\hline Foreign MA dummy & $\begin{array}{c}-0.062 \\
(0.067)\end{array}$ & $\begin{array}{c}-0.051 * \\
(0.027)\end{array}$ & $\begin{array}{c}-0.054 * \\
(0.030)\end{array}$ \\
\hline Foreign MA $*$ trend & $\begin{array}{c}0.000 \\
(0.001)\end{array}$ & & \\
\hline Foreign De Novo dummy & $\begin{array}{c}0.038 \\
(0.109)\end{array}$ & $\begin{array}{c}0.079 \\
(0.088)\end{array}$ & $\begin{array}{c}0.077 \\
(0.133)\end{array}$ \\
\hline Foreign De Novo $*$ trend & $\begin{array}{c}0.002 \\
(0.002)\end{array}$ & & \\
\hline Trend & $\begin{array}{l}-0.000 \\
(0.000)\end{array}$ & & \\
\hline Net int. margins & $\begin{array}{c}-0.122 \\
(0.274)\end{array}$ & $\begin{array}{l}-0.115 \\
(0.222)\end{array}$ & $\begin{array}{c}-0.123 \\
(0.245)\end{array}$ \\
\hline Cash over assets & $\begin{array}{c}-0.600 * * * \\
(0.128)\end{array}$ & $\begin{array}{c}-0.597 * * * \\
(0.125)\end{array}$ & $\begin{array}{c}-0.594 * * * \\
(0.128)\end{array}$ \\
\hline Admin costs over assets & $\begin{array}{c}0.643 \\
(0.518)\end{array}$ & $\begin{array}{c}0.547 \\
(0.472)\end{array}$ & $\begin{array}{c}1.021 * * \\
(0.503)\end{array}$ \\
\hline NPL over loans & $\begin{array}{l}-0.163 \\
(0.116)\end{array}$ & $\begin{array}{l}-0.153 \\
(0.114)\end{array}$ & $\begin{array}{c}-0.176 \\
(0.114)\end{array}$ \\
\hline Equity Ratio & $\begin{array}{c}0.163 \\
(0.155)\end{array}$ & $\begin{array}{c}0.159 \\
(0.154)\end{array}$ & $\begin{array}{c}0.171 \\
(0.164)\end{array}$ \\
\hline Constant & $\begin{array}{c}0.542 * * * \\
(0.073)\end{array}$ & $\begin{array}{c}0.470 * * * \\
(0.060)\end{array}$ & $\begin{array}{c}0.518^{* * *} \\
(0.053) \\
\end{array}$ \\
\hline Observations & 1,035 & 1,039 & 1,039 \\
\hline Number of banks & 40 & 41 & 41 \\
\hline $\mathrm{R} 2$ overall & 0.15 & 0.21 & 0.21 \\
\hline $\mathrm{R} 2$ between & 0.11 & 0.09 & 0.07 \\
\hline R2 within & 0.23 & 0.23 & 0.23 \\
\hline
\end{tabular}

Dependent variable is total private loans to assets (private loans are the sum of commercial, consumer, and housing loans). The sample goes from September 1997 to December 2011. All estimations include quarterly dummies. Robust Standard Errors clustered at the bank level. Significance of 1, 5, and 10 per cent denoted by $* * *, * *$, and $*$, respectively. 